\title{
THE RETURNS TO EDUCATION: MACROECONOMICS
}

\author{
Barbara Sianesi \\ Institute for Fiscal Studies \\ John Van Reenen \\ University College London
}

\begin{abstract}
We offer an extensive summary and a critical discussion of the empirical literature on the impact of human capital on macro-economic performance, with a particular focus on UK policy. We also highlight methodological issues and make recommendations for future research priorities.

Taking the studies as a whole, the evidence that human capital increases productivity is compelling, though still largely divided on whether the stock of education affects the long-run level or growth rate of GDP. A one-year increase in average education is found to raise the level of output per capita by between three and six percent according to augmented neo-classical specifications, while leading to an over one percentage point faster growth according to estimates from the new-growth theories. Still, over the short-run planning horizon (four years) the empirical estimates of the change in GDP are of similar orders of magnitude in the two approaches. The impact of increases at different levels of education appear to depend on the level of a country's development, with tertiary education being the most important for growth in OECD countries. Education is found to yield additional indirect benefits to growth. More preliminary evidence seems to indicate that type, quality and efficiency of education matter for growth too.
\end{abstract}

Keywords. Education; Productivity; Public Policy; Economic Growth; Human Capital

\section{Introduction}

Crucial decisions facing modern governments concern educational expenditure and the provision of education. The evidence from labour economics consistently points to substantial monetary returns accruing to individuals investing in education. However these individual level analyses (surveyed in the contribution in this journal by Harmon, Oosterbeek and Walker, 2002) can at most recover estimates of the private returns to education, which may underestimate the full returns to society if education has the characteristics of a public good. In other words, the benefits of individually acquired education may not be restricted to the individual but might 'spill over' to other individuals in the same firm, industry, city, region 
or economy. It is in fact these social returns at the macro level that should provide the relevant economic justification for the public support of education.

In this review we focus on a number of empirical economic studies which help shed light on these wider benefits of education, at least as captured by indicators of economic performance (see also Temple, 2001). Our primary objective is to critically review the literature that has tried to estimate the impact of human capital on national economic growth, or, in other words, the returns to education that accrue at the macro-economic level. The potential economic externalities to education should, in principle, be captured at this level of aggregation. The larger are these social returns, the greater is the prima facie case for channelling public resources into education. ${ }^{1}$

In particular, the main aims of the paper are the following:

\section{1. to highlight the key research findings which emerge from the macro growth regressions}

We offer an extensive summary and discussion of the macro growth regressions - a body of econometric literature trying to measure the links between education and economic growth. In Section 4 the results of over twenty empirical contributions to the debate are detailed, with Tables 1 and 2 offering an analytic summary of the studies and attempting to make quantitative comparisons of the implied effect of education across all of them (an Appendix is available, with a one page summary of each paper including abstract, data, method, results and critique).

2. to provide an estimate of the most plausible social return to education

In addition, to help quantify such an effect for an economy sharing the relevant features of the UK, in Section 4.2 we give some quantitative estimates of the social returns in money terms based on the central estimates obtained in the literature.

3. to report on other major findings in the literature

In particular, key differences in the effects of schooling in different types of countries; the impact of different types of schooling; and education quality and delivery issues are also addressed in Sections 4.1 and 4.3.

4. to identify gaps in the literature and to suggest ways to advance it

Areas in which future work is needed are suggested in Section 5.

Secondary issues include:

\section{5. to highlight the interplay between theoretical developments and empirical methods}

Several approaches to modelling human capital and economic growth have been explored and we offer a methodological description, critique and evaluation of each.

As detailed in Section 2, a basic distinction is between the augmented neoclassical model and the new endogenous growth theories. Such a distinction is important because in the new growth framework a policy intervention to raise 
the level of human capital (e.g. through higher schooling subsidies) has a much larger effect on economic welfare than it would do in the neo-classical model. 6. to discuss methodological issues

Section 3 offers a non-technical critique of these methodologies, including data problems and econometric issues (Temple, 1999 is the recommended source for a thorough and more technical discussion).

A crude summary of the main results is the following.

Taking the studies as a whole, there is compelling evidence that human capital increases productivity, suggesting that education really is productivity-enhancing rather than just a device that individuals use to signal their level of ability to the employer. Most of the evidence is from 'Barro' style growth regressions that suggest that increasing school enrolment rates by one percentage points leads to an increase in per capita GDP growth of between one and three percentage points every year.

The empirical literature is largely divided over whether the stock of education affects the long-run level (augmented neo-classical approach) or long-run growth rate (new growth theories) of the economy. Increasing average education in the population by one year would raise the level of output per capita by between three and six percent according to the former approach, while it would lead to an over one percentage point faster growth according to the latter — an extraordinarily large effect. We think the effect is overstated due to methodological problems such as correlation with omitted variables and the imposition of restrictions that are rejected by the data. We conclude, therefore, that the evidence in favour of the new growth theories (especially for OECD countries) is quite weak due to a whole host of problems. Our baseline estimates follow the augmented neo-classical specification pioneered by Mankiw, Romer and Weil (1992) and look for effects of the human capital stock on the level of output, although we compare this carefully with estimates from the alternative growth approach. Interestingly, it turns out that over the short-run planning horizon (4 years ahead) the empirical estimates of the change in GDP for a given increase in the human capital stock are of similar orders of magnitude in the two approaches.

More qualitative results include:

- Schooling returns are generally higher in LDCs than in the OECD;

- The impact of increases in various levels of education appears to greatly depend on the level of a country's development (with tertiary education being the most relevant for OECD countries);

- Education yields additional indirect benefits to growth (in particular, by stimulating physical capital investments and technological development and adoption);

- Schooling quality, as well as the efficiency with which resources are allocated to the various levels of education matter considerably, since they not only directly impact on economic growth, but also affect the impact of the quantity of education on growth. 


\section{Theoretical Frameworks and Empirical Methods}

\subsection{Introduction}

The aim of this section is to outline the main theoretical approaches modelling the linkages between human capital and economic performance, together with a methodological description of the empirical analyses based on such theory. The section starts by introducing the important notion of educational externalities (2.2), a concept which largely explains why the typical modelling attempts take place at the macro level.

The two main macro approaches are the augmented Solow neo-classical approach (2.3) and the 'new growth theories' (2.4), with their empirical respective counterparts of growth accounting exercises (2.3) and macro growth regressions (2.5).

The augmented neo-classical model simply extends the basic production function framework to allow an extra input to enter the production function: human capital. Since this is estimated at the economy-wide level it does take into account human capital externalities which increase the level of output. The endogenous growth approach argues that there should be an additional effect of human capital over and above the static effect on the level of output. Based on the notion that a higher rate of innovation is associated with economies richer in human capital, increasing the level of human capital is expected to have an effect on the growth rate of productivity.

The idea of positive educational externalities is well established (though still largely untested). This partly explains the paucity and controversial nature of micro level studies of social rates of returns estimates (2.6). A few attempts have very recently emerged in the micro-econometric literature looking at educational externalities, defined however in a limited way, as the 'impact of average education on individual earnings' (2.7). The final sub-section (2.8) considers the microeconometric literature on private individual returns to education, as well as its linkages to the macro approaches just discussed.

\subsection{Externalities}

Economists have long argued that the benefits of human capital accumulation may not be restricted to the direct recipient but might also spill over to others. Some of the new growth theories (cf. 2.4) have distinguished themselves from the traditional neo-classical approach by explicitly proposing a role for education externalities in economic growth. Channels for such types of externalities include the possibility that educated workers may raise the productivity of their less educated co-workers, that there may be spill-over effects from technical progress or knowledge accumulation which in turn arise from investments in human capital, or that an environment with a higher average level of human capital may entail a higher incidence of learning from others.

Investments in human capital may also have external social impacts, which can in turn have indirect economic effects. More education has for instance been found to be associated with better public health, better parenting, lower crime, 
a better environment, wider political and community participation, and greater social cohesion, all of which is in turn likely to feed back into economic growth (see OECD, 1998 for a synthetic review and relevant references).

The existence of positive economy-wide educational spill-overs (by definition not taken into account in individual decisions on educational investments) is an important economic justification for the public support of education and is often assumed a priori by theorists and policymakers alike, although the difficulties of actually verifying their size and thus calculating true social returns are formidable.

While there is a large amount of evidence arising from microeconometric studies on the returns to education to the individual, macro studies are especially relevant in terms of assessing the empirical importance of educational externalities, since regressions looking at the macroeconomic impact of human capital are well positioned to capture these wider effects of such investments on national economic growth.

In addition to these regressions at the macro level (section 2.3, 2.5), a few papers look at the impact on individual wages of the average level of education in the individual's city or state of residence (section 2.7), and so try to counter Topel's (1999) remark that 'labour economists are conspicuous by their absence' on the subject of the social returns to education.

\subsection{The Solow (or Neo-classical) Model and Growth Accounting}

Consider the definition of the aggregate production function, where GDP $Y$ is modelled as a function of the aggregate stock of physical capital $K$ in the economy, its labour force $L$ and time $t$, which captures otherwise unmodelled 'technical progress'. In symbols:

$$
Y_{t}=f\left(K_{t}, L_{t}, t\right)
$$

Define $M P_{n} \equiv \delta f(.) / \delta n$ to be the marginal product of factor $n$, i.e. the contribution to output of an increment in input $n$, holding constant all other production factors. Simple algebra yields (where a dot denotes the derivative with respect to time):

$$
\frac{\dot{Y}}{Y}=\frac{M P_{K} K}{Y} \frac{\dot{K}}{K}+\frac{M P_{L} L}{Y} \frac{\dot{L}}{L}+\frac{\partial f / \partial t}{Y}
$$

Assuming perfect competition and constant returns to scale ${ }^{2}$ further gives:

$$
g_{Y}=\theta g_{K}+(1-\theta) g_{L}+g_{t}
$$

where $g_{n} \equiv \dot{n} / n$ is the percentage growth rate of factor $n$ and $\theta$ is the share of output accruing to capital.

Note that these assumptions rule out externalities a priori.

The rate of growth of output is thus decomposed into its constituent parts - the contribution of factor inputs and of residual total factor productivity $g_{t}$ - by weighting the growth in each input by its relative factor share. 
The parameters of the aggregate production function are mostly imposed (typically around 0.3 for both physical and human capital) or calibrated based on micro evidence.

Such accounting exercises are then mainly aimed at assessing the relative contribution of inputs (physical and human capital) versus residual total factor productivity (or the efficiency with which these inputs are used) to either (a) growth in output or (b) cross-country differences in output per worker.

More precisely,

(a) in 'growth accounting' exercises, a country's growth in output is decomposed into the growth rates of inputs (i.e. input accumulation) and in residual productivity growth;

(b) in 'level accounting' exercises, differences in output per worker across countries are decomposed into cross-country differences in productivity and in input intensities. In particular, according to the Solow model, cross-country differences in levels of real income per person and rates of economic growth should be explained by variations in national population growth and savings rates, where the lower the population growth rate and the higher the savings rate, the richer the economy.

The so-called puzzle of the 'residual' (the six sevenths proportion of output growth that could not be attributed to growth in capital and labour in Solow's seminal 1957 study) made it clear that the growth of real income per capita cannot be fully accounted for by increases in the quantities of the capital and labour inputs alone.

While growth theories began to be built around the 'residual', Solow's (1957) paper stimulated a great amount of empirical work in the 1960s to diminish the importance of the residual by extending the framework. In particular, the quality of inputs was explicitly included through investment in both education (i.e. accumulation of human capital) and in $R \& D$ giving rise to technical change, while advances were made in measuring capital, so as to allow for different types and vintages (see Griliches, 1996, for some of the intellectual history).

Despite these new developments, though, the issue remains that 'accounting is no explanation' (Griliches, 1997). In fact, an implicit assumption in this literature is that the observed differences between the market rewards of the various education levels are exclusively due to education itself. In general, however, the observed relationship between individual wages and education levels does not reflect the causal effect of education on wages, since potential sources of bias may arise due to individual education choices; for instance, individuals of higher unobserved ability or with higher unobserved payoffs from schooling may invest more in education. (For a non-technical discussion of these issues see Harmon, Oosterbeek and Walker, 2002; for a technical review of alternative microeconometric models and estimation methods meant to overcome these sources of bias in the estimation of the individual wage returns to different levels of education, see e.g. Blundell, Dearden and Sianesi, 2002).

In addition, these exercises capture none of the potential indirect effects that education can have on output levels or growth (e.g. through physical investments, 
labour force participation, or R\&D). Thus even if productivity growth has been allocated in detail to the various components, the existence of such a positive correlation tells us nothing about causal relationships, about the mechanisms, the processes through which human capital accumulation affects economic growth.

\subsection{The 'New Growth Theories'}

In contrast to the traditional neo-classical Solow growth model, the recently emerged 'new growth economics' theories emphasise the endogenous determination of growth rates, which are determined within the model (and can thus be affected e.g. by government policies), instead of being driven by exogenous technological progress.

While education has no role in traditional neo-classical theories of economic growth, these new approaches have explicitly brought the role of education to the fore. They provide the theoretical underpinnings for assuming that education can affect national economic growth via two main channels:

(a) Human capital is explicitly incorporated as a factor input in the production function, by - in contrast to the augmented neo-classical model — explicitly modelling individual educational investment choices, as well as often allowing human capital to have external effects, thus departing from the constant returns to scale assumption.

(b) The factors leading to endogenous growth (in particular technological change) are explicitly related to the stock of human capital. This may be either because human capital is assumed to directly produce new knowledge/ technology or because it is an essential input into a research sector which generates new knowledge/technology.

There are accordingly two strands of thought in the new growth approaches, which respectively focus on the effects of (a) the accumulation (or 'flow') of human capital and of (b) the stock of human capital.

This distinction has important implications. In particular, any policy measure such as a subsidy to education which raises the level of human capital will have a once-and-for-all effect on output in the first framework, but will increase the growth rate of the economy forever in the second one. There is no consensus in the empirical literature over which is the appropriate approach. ${ }^{3}$

In fact, the evidence on the neo-classical vs. endogenous growth models is still inconclusive. The available macro evidence does not allow us in general to distinguish between theories, since most of them (although hypothesising different ways in which human capital might enhance growth) are observationally equivalent. They yield similar predictions relating to the impact of some human capital variable on growth. For example, output growth is predicted to be a function of the rate of growth of human capital not only in the neo-classical growth accounting exercises, but also in the endogenous growth approach (a) above.

More generally, macro regressions have not really tried to test one theory against the other, but have tended to emphasise an expanded set of variables suggested by the new literature. 
Most of these regressions include the stock of human capital as an explanatory factor and take inspiration and justification — albeit quite loosely — from the endogenous growth strand outlined in (b) above (the 'stock of human capital approach'). It is important to note that in such cases the estimated increase in productivity is not simply a phenomenon of the transitional period as the increase in the flow of education leads to a gradual increase in the equilibrium human capital stock. Implicitly it is claimed that increasing average education in an economy will permanently increase the rate of economic growth, even after the human capital stock has adjusted to its new long-run level.

\subsection{Macro Growth Regressions}

Following the release of the Summers-Heston cross-country dataset, there has been an outpouring of cross-country empirical work carried out by macroeconomists trying to explain post-1960 cross-country growth performances.

Unlike conventional growth and level accounting (see section 2.3), this 'new growth evidence' exploits cross-country variation in the data to estimate, rather than impose the parameters (output elasticities) of the aggregate production function. It tries to explain the cross-country variation in total factor productivity growth, which was left unexplained in the growth accounting exercises.

Most of these analyses group developing and developed countries together and there is considerable overlap in the data sets and specifications used by the different studies. These regressions, sometimes termed 'Barro regressions', are informal ad hoc regressions, in which the choice of explanatory variables is largely driven by previous results in the literature and a priori considerations.

The measure of productivity is often aggregate real GDP per capita (or per worker or per working-age person). Regressors typically include proxies of human capital, initial level of GDP, physical investment ratios, geographical dummies, and a number of variables that capture the role of governments, such as real government consumption ratios, political stability indicators, measures of market distortions and economic system indicators.

The aim of such macro regressions is to investigate the respective role of the various 'inputs' in contributing to economic growth, thus shedding some light on the origin of differences in growth rates across countries, and helping to identify those policy measures most likely to enhance growth.

Despite the prevailing use of cross-country variation, some recent studies have been trying to exploit the time-series information for one or more countries in a panel approach. Such pooled cross-country time-series data can be used to explain both the cross-country differences in growth as well as the evolution of the performance over time in each country. The main advantages are the possibility of controlling for unobserved and thus omitted variables that are constant over time but may be correlated with some of the regressors (like the initial level of technological efficiency) and the ability of using several lags of the instruments to control for endogeneity biases (e.g. allowing GMM estimation of dynamic 
models). The use of fixed-effects estimation techniques however prevents the analysis of the impact on growth of variables that do not change much over time, as well as exacerbating measurement error (for more details, see Temple, 1999).

\subsection{Social Rates of Return}

The internal rate of return method is a purely accounting approach which evaluates the profitability — private or social — of any given investment by looking at the properly discounted flow of benefits and costs arising from that investment. The internal rate of return, which is given by that discount rate for which the discounted present value of the benefits arising from the investment net of its costs equals zero, can then be compared to the reference discount rate of the decision-maker.

When applied to the assessment of the social profitability of an investment in human capital, the 'social rate of return' is the internal rate of return of such an investment, evaluated from a social point of view. In other words, it is given by that discount rate for which the present discounted value of all social benefits equals the present discounted value of all social costs. A correctly calculated social rate of return should be the one guiding the decisions societies make to collectively finance education.

Compared to private rates of returns, these 'social' rates of return include all of the direct costs of schooling (and not just those borne by the individual) and use pre-tax (instead of post-tax) earnings. By contrast, the private rates of return estimates assume that the only cost of education is foregone earnings (because of public subsidy of direct schooling costs) and that earnings are net of taxes. Thus, in practice, the calculations performed are accounting exercises, which provide estimates of the returns to education that include net transfers (i.e. subsidies to education and income taxes).

These 'social' rate estimates should however be regarded as a lower bound of the full returns to education. All the costs of education are included while broader non-employment personal benefits are excluded (e.g. externalities in the form of macroeconomic and social gains, and the lower risk of unemployment faced by individuals with more education).

OECD (1998, Figure 4.4) reports social rates of return to different levels of education, calculated for various OECD countries. 'Social' rates are consistently found to be lower than private ones. In general, almost all the difference between the social and private rates of return appears to be due to the direct cost of schooling.

\subsection{Wage Regressions}

A recently emerged methodology aims at identifying educational externalities by isolating the causal impact on individual wages of the average level of education in the city or state of residence of the individual. 
The basic equation is of the form

$$
Y_{i j t}=X_{i}^{\prime} \mu+\delta_{j}+\delta_{t}+\gamma_{1} \bar{S}_{j t}+\gamma_{2 i} s_{i}+u_{j t}+\varepsilon_{i}
$$

where $i$ denotes the individual, $j$ the state (or the city) and $t$ time. Individual log weekly wages $Y$ are regressed on individual characteristics $X$, state-of-residence (or city) and year effects $\delta$, state (or city) average schooling $\bar{S}$ and individual schooling $s$.

The main technical problem which has to be addressed in such a framework is the likely endogeneity of $\bar{S}$ and $s$ due to the presence of unobserved factors affecting both wages and the amount of schooling an individual decides to invest in, or affecting wages as well as the percentage of educated workers in a state/city.

Other potential weaknesses relate to the very specific definition of educational externality adopted. In particular, positive effects may accrue at a higher (national) or lower (firm) level of aggregation. In addition, average education may provide externalities not captured by workers through their wages: individuals may benefit in a non-pecuniary form (e.g. type of tasks, supervisory effort, quality of working and living environment) and spill-over effects may in part accrue to employers instead.

The work by Moretti (1999) and by Acemoglu and Angrist (1999) provide examples of this approach (for more details on these papers, see the appendix).

\subsection{Reconciling Micro and Macro}

A first type of 'micro' studies concerning human capital investments is the social rate of returns approach outlined in Section 2.6. Such studies and the macro growth regressions are aimed at measuring two conceptually quite distinct quantities. Growth regressions try to 'allocate' cross-country differences in economic growth to the various 'inputs'. So, for education, they yield estimates of the impact that educational investments have had on macroeconomic growth.

By contrast, social rates of return studies try to calculate the (social) internal return of educational investments, as that rate of return which exactly balances individual and tax benefits with social costs. The outcome of the exercise should thus be compared to other relevant rates (e.g. social discount rates, rate of other investments, interest to be paid on borrowed funds etc.) to decide (or predict) if the investment was worthwhile.

While allowing us to explicitly consider the largely neglected cost side, social rates of return studies do not include externalities in their calculation, while one justification for macro growth regressions is precisely their potential ability to capture economy-wide indirect or spill-over effects from educational investments.

Traditional microeconometric evidence is usually based on estimating individual earnings equations of the form of equation (1) setting $\gamma_{1}=0$. Card (1999) provides a comprehensive review of this literature that suggests that the coefficient on individual years of schooling when estimated by OLS is usually around 6-11\%. Similarly, the interesting meta-analysis by Harmon, Oosterbeek and Walker (2002) shows a striking similarity in the OLS-estimated returns for 
various cuts of the data, with an average return of $6.5 \%$ across most countries and model specifications. Controlling for the potential endogeneity of schooling by using twins, 'natural experiments' or other instrumental variables does not generally reduce the size of the private return (in fact the size of the coefficient usually increases - see again Card, 1999 and Harmon, Oosterbeek and Walker, 2002).

Still, a priori, the social return from education may be higher or lower than the private return estimated from such micro studies. It can be higher due to positive externalities arising from individual educational investments (cf. Section 2.2), but if educational degrees are simply used as a device to signal higher innate ability without raising individual productivity, the social rate will be less than the private one. Yet another possibility pointed out by Krueger and Lindahl (1998) relates to the finding that in developing countries higher education is positively associated with unemployment, so that an increase in the level of education may actually reduce total output.

Although from the micro evidence on earnings it cannot be decided whether the social return to education exceeds the private gains, other micro evidence points to positive externalities in the form of lower crime, reduced welfare dependence, better public health and parenting, all factors that are likely to positively affect economic productivity.

There is a much smaller body of literature which has estimated the return to human capital by entering schooling or training directly into a production function at the enterprise or industry level (see e.g. Dearden, Reed and Van Reenen, 2000). This literature does hint that the returns to human capital are larger for firms than individuals suggesting that not all of the productivity gains are captured by workers.

As discussed above the macro estimates have the advantage that they should be able to capture externalities that are ruled out in the standard approach. The micro estimates could thus be used to estimate the private return and the macro estimates could be used to estimate the social return. The problem, however, is that there are many more methodological problems in interpreting the coefficient on education in the macro approach than the micro approach. The larger coefficients in the macro literature could simply be due to 'aggregation biases' of various sorts, as well as to the undue imposition of restrictions (notably of linearity and homogenous impact of education). We now turn to this set of methodological problems.

\section{Methodological Issues}

\subsection{Data and Proxies}

\section{Measurement of human capital}

A first issue is how to define, measure and compare skills and competencies over time and between countries (see de la Fuente and Doménech, 2000, for a brief survey of available educational data bases). The best measures would be in terms 
of the output of education, but due to the difficulties of obtaining such measures, input measures tend to be used. It is very difficult to know how close proxies such as school enrolment, average years of education or the proportion of the labour force which has received primary, secondary or tertiary education, are to their conceptual equivalents, so that failure to find positive evidence could be due to poor proxies.

In particular, such aggregate measures are likely to be affected by several problems:

- These studies are based on formal educational attainment only, without considering wider definitions of human capital investment encompassing on-thejob training, experience and learning-by-doing, and ignoring its depreciation.

- The quality of education is not taken into account.

- Different types of education may have differential impacts on economic performance.

- As to the conceptual variables and their empirical proxies, it is often unclear whether the widely used school enrolment rates variable is intended to capture the flow of investment in human capital or else its stock. 'In practice, these rates may be a poor proxy for both' (Temple 1999, p.139; cf. the work by Gemmel, 1996).

\section{Data quality}

The quality of the data on the numerous variables used to explain income levels or growth rates varies widely across countries. For example, data on output (including missing information on the non-market sector) and other variables (in particular for net investment, capital stocks, labour force participation and working hours) is likely to be particularly poor (if not missing) for certain developing countries.

Furthermore, few studies try to assess the sensitivity of their results to measurement error. This may severely bias the estimates concerning schooling data, especially when changes in education are calculated. Krueger and Lindahl (1998), for instance, find that the correlation between the measures of average education from two main sources of educational data (Barro-Lee and Kyriacou) is 0.86 , decreasing further to 0.34 if changes in schooling are considered. They also find that measurement error is particularly severe for years of secondary and tertiary education, and that measurement errors are positively correlated over time. Similarly, the analyses by de la Fuente and Doménech (2000) highlight the implausible time-series and cross-section profiles arising from existing data on educational attainment due to changes in classification criteria and other inconsistencies.

\section{Data sources and variables}

Datasets for the various studies are typically collated from a variety of sources, depending on the focus of the analysis (see the appendix for a succinct data description for each study). The first version of the 'Penn World Tables' by Summers and Heston in 1991 has probably been the most influential one. The Summers-Heston 
dataset provides GDP measures constructed in a roughly consistent way for the various countries. This has now been updated and combined with other 'popular' data collections, such as the one by Barro and Lee (which has education measures) or the alternative source of schooling data provided by Kyriacou.

The measure of productivity is either aggregate, per worker, per capita or per working-age person real GDP, labour productivity or total factor productivity. Proxies of human capital are:

- indicators of human capital stock and flows constructed by each author,

- school enrolment rates by gender and sometimes by level (primary, secondary, tertiary),

- average years of education,

- the proportion of the labour force which has received education at different levels.

Typical regressors include other human capital indicators such as life expectancy or fertility rates, the initial level of GDP, physical investment ratios, geographical dummies, terms of trade changes, and a number of variables that capture the role of governments (real government consumption ratios, inflation rates, political stability indicators, measures of market distortions, democracy indexes, rule of law indexes and economic system indicators).

\subsection{Endogeneity Bias}

As income grows, educational standards rise, but we cannot be confident that economic growth is caused by higher educational standards.

There are in fact reverse causality problems with education: the association of education and productivity growth may reflect the demand for education, as well as its supply effects. Education contains a large consumption component; if the demand for it is highly income-elastic, income growth is likely to lead to an increased demand for education. Industrialised countries' governments in turn will be more able to respond with an increase in public spending for education and an enlargement of access to it.

Also, in countries at higher income levels that have already gone through the stages of development, a larger incidence of the service sector and of the modern, high-tech production sectors will require a better-educated workforce. The question is whether the upgrading process is sparked and made possible by an (exogenously) increasingly available educated workforce (impact of human capital accumulation on growth) or whether the structural change induces larger fractions of the population to achieve higher educational standards (impact of economic growth on human capital accumulation). The most plausible answer is that both influences are simultaneously at work, so that there is a bi-directional causality between human capital accumulation and economic growth.

An additional issue relates to the overall efficiency of an economy. One could for instance expect those countries which are more efficient at turning educational inputs into educational outputs to also be more efficient at allocating 
non-educational resources, thus resulting in both higher educational levels and faster growth.

These considerations point to the fact that human capital accumulation is likely to be endogenous, and failure to control for this may lead to a simultaneity bias.

Other endogeneity problems are likely to affect several widely used variables as well, such as the investment ratio. Given the wide range of variables used to explain growth, there is a shortage of plausible instruments.

The standard approach of relating growth to the initial value of an explanatory variable (such as the 1960 school enrolment) may not be robust. First, it does not avoid the danger that there may be some other factor, like the political regime, which jointly affects growth and variables like initial school enrolment (Aghion and Howitt, 1998). Secondly, expected favourable future economic prospects may induce individuals to invest more in education. When longitudinal datasets are available, one possibility is to use lags of the endogenous variables as instruments. The exogeneity of such lagged variables can however be questioned (Temple, 1999), especially since there may be long — and unknown — delays in the effect of human or physical capital accumulation on growth.

\subsection{Parameter heterogeneity}

Cross-country growth studies tend to include countries at very dissimilar levels of development in order to maximise the size of their samples, and the models estimated invariably assume - and constrain — the impact of education to be homogenous across countries.

The results are thus an average from very heterogeneous countries, resulting from a comparison of mean attainment across countries whose systems vary widely in terms of content, sequence and quality (see Lee, Pesaran and Smith, 1997).

On the other hand, when estimating the relationship for a subgroup of more homogeneous countries (e.g. the OECD), the results have to be interpreted with care due to the small size of the sample. In fact, most authors have noted that the estimates for the OECD subgroup alone are much less precise, although very recent developments exploiting new harmonised data have obtained more stable results (cf. 4.1.4). Splitting the sample according to the level of development clearly shows that various regressors have a different impact for the two (or three) sub-samples. Such a heterogeneous impact is also consistent with the micro evidence, which points out that the (individual) returns to education considerably vary across countries, and even across regions within countries.

There is thus considerable evidence on the existence of heterogeneity across countries in the parameters of the growth regression. This raises the questions of how much such regressions tell us about parameter averages and of how reliable it is to extrapolate results obtained on such a mixed sample to policy prescriptions for specific countries. In particular, it is quite dubious to use an estimate derived from a pool of such diverse countries to make inference as to the impact of educational expansions in the UK. 
Krueger and Lindahl (1998) are the only study that has so far, to our knowledge, tried to assess the impact of relaxing the constant-education-slope assumption commonly maintained in the macro growth regressions. They find such an assumption to be strongly rejected by the data, and that the average effect of education is statistically insignificant. They conclude that 'these results cast doubt on the interpretation of education in the constrained [to have a homogenous impact] macro growth equation common in the literature' (p.34).

\subsection{Model uncertainty}

The correlations found in the literature have been found to crucially depend on the choice of the additional regressors included (Levine and Renelt, 1992). In particular, most regressors have been found very fragile, in the sense that their estimated parameters change sign or become statistically insignificant when a different group of regressors is included. Together with the fact that many alternative regressions have equal theoretical status, such findings call for a great deal of care in the interpretation of cross-country results.

\subsection{Non-linearities}

Given the mostly ad hoc nature of the macro-economic specifications, there is no strong a priori reason to assume a linear relationship between human capital and productivity levels or growth. In fact one might expect diminishing returns to a factor (as in the conventional log-log Cobb-Douglas production function). One of the few studies that has examined this issue is Krueger and Lindahl (1998). They find evidence for non-linearities, in particular they find that a quadratic form for schooling fits the data better (a squared term is significant). The inverted-U pattern suggests that there are diminishing returns to education, with the peak effect at about 7.5 years. ${ }^{4}$ The presence of non-linearities is also consistent with other forms of mis-specification (generally simple aggregation of a non-linear micro relationship renders the coefficients on the nonlinear macro equation uninterpretable).

\section{Results}

\subsection{Comparing the Empirical Magnitudes of the Effects of Human Capital on Growth}

The estimates of the impact of human capital on economic performance that have been produced by the various studies reviewed here are not directly comparable.

A first crucial difference is the one between cross-country regressions and growth (and level) accounting. Such a difference arises from the different methodology and different aim of the respective empirical investigations. 


\subsubsection{Growth and Level Accounting}

Accounting exercises (cf. Section 2.3) are mainly aimed at assessing the relative contribution of inputs (physical and human capital) versus residual total factor productivity (or the efficiency with which these inputs are used) to either growth in output or cross-country differences in output per worker. For this line of research, the relevant figures to compare are thus the weight (in terms of percentage contribution to explaining the growth in output or the cross-country variance in output) of physical and human factors on the one hand and of productivity on the other.

Table 1 contrasts some major studies conducted along these lines.

$Y$ is the outcome being evaluated (cross-country differences in GDP per worker in a given year, cross-country differences in GDP per worker growth rates over a given period or GDP growth rates of a given country over time). The analyst tries to apportion the outcome between the contribution of (unexplained) total factor productivity (or efficiency) $A$ and measured factor inputs $X$ - themselves in turn broken down into physical capital stock $K$ and labour (including human capital) $H$.

The core of the debate concerns the relative weight of $A$ versus $X$.

Older studies (e.g. Jorgenson and Fraumeni, 1992 and Mankiw, Romer and Weil 1992) seem to point to the importance of factor intensities and accumulation. From the table the basic findings from the first study, for instance, can be summarised as follows: investments in human and physical capital account for most $(83 \%)$ of US economic growth between 1948 and 1986. Growth in labour input in particular accounts for $61 \%$ of economic growth, of which less than half $(42 \%)$ is due to increases in labour quality.

By contrast, more recent studies have questioned such results and the methodologies underlying them. Hall and Jones (1999) as well as Klenow and Rodriquez (1997), for instance, claim that residual productivity $(A)$ is by far the most important component. International output differences are largely (over 60\%) accounted for by differences in productivity, and similarly, differences in growth rates of income per worker derive overwhelmingly (up to 90\%) from differences in growth rates of $A$. Focussing on the more homogeneous sample of OECD countries alone and using panel data, de la Fuente and Doménech (2000) find that the relative importance of total factor productivity differences is considerable and has been increasing over time to account for about one half of the observed productivity differentials.

It is important to stress that output elasticities with respect to inputs are either imposed (typically around 0.3 for both physical and human capital) or equated to their shares in value added (the latter requiring perfect competition and constant returns to scale). In this framework, then, the question of how much output would increase if human capital were increased by $1 \%$ is misplaced, the answer being imposed a priori and not resulting from the analysis. A second issue is that the 'human capital' aspect of the labour input is not in general easy to be separately identified. This is because the 'labour' input used is often a combined measure of various educational, demographic and labour force variables 
Table 1. Growth and Level Accounting: $Y=A X$.

Contribution of residual total factor productivity $A$ versus input factors $X-$ physical capital $K$ and human capital $H-$ to output $Y$

\begin{tabular}{|c|c|c|c|c|c|}
\hline & \multirow{2}{*}{$\frac{\mathrm{Y}}{\text { Output }}$} & \multirow{2}{*}{$\frac{\mathrm{A}}{\mathrm{TFP}}$} & \multicolumn{2}{|r|}{$X$} & \multirow[b]{2}{*}{ Elasticities } \\
\hline & & & $\begin{array}{c}\text { K } \\
\text { Physical capital }\end{array}$ & $\begin{array}{c}\mathrm{H} \\
\text { Human capital }\end{array}$ & \\
\hline $\begin{array}{l}\text { Jorgenson- } \\
\text { Fraumeni } \\
(1992) \\
\rightarrow \mathbf{X}\end{array}$ & $\begin{array}{l}\text { Growth accounting: } \\
\text { output growth rates, } \\
\text { US 1948-86 }\end{array}$ & $17 \%$ & $22 \%$ & $\begin{array}{l}61 \% \text { (labour input) } \\
\text { of which } 42 \% \text { accounted } \\
\text { by labour quality. Thus } \\
\text { labour quality accounts } \\
\text { for } 26 \% \text { of economic } \\
\text { growth. }\end{array}$ & $\begin{array}{l}\text { Shares of the inputs in } \\
\text { aggregate value added }\end{array}$ \\
\hline $\begin{array}{l}\text { Mankiw, } \\
\text { Romer and } \\
\text { Weil (1992) } \\
\rightarrow \mathbf{X}\end{array}$ & $\begin{array}{l}\text { Level accounting: } \\
\text { cross-country } \\
\text { differences in } \\
\text { output per } \\
\text { worker, } 98 \\
\text { countries in } \\
1985\end{array}$ & $22 \%$ & $29 \%$ & $49 \%$ & $\begin{array}{l}\text { Estimated: } \\
\text { For } K=0.31 \\
\text { For } H=0.28 \\
\text { Thus raising } H \text { per } \\
\text { worker by } 1 \% \text { leads } \\
\text { to a } 0.28 \% \\
\text { increase in } Y \text { per } \\
\text { worker. }\end{array}$ \\
\hline $\begin{array}{l}\text { Hall and } \\
\text { Jones (1999) } \\
\rightarrow \mathbf{A}\end{array}$ & $\begin{array}{l}\text { Level accounting: } \\
\text { cross-country } \\
\text { differences in } \\
\text { output per worker, } \\
127 \text { countries in } 1988\end{array}$ & $\begin{array}{l}\quad 61 \% \\
\text { Percent cc } \\
5 \text { countrie } \\
5 \text { lowest } \\
\text { higher the }\end{array}$ & $\begin{array}{l}\qquad 17 \% \\
\text { ion to the differenc } \\
\text { he highest level of } \\
\text { ies }(Y \text { per worker } \\
\text { e latter) }\end{array}$ & $\begin{array}{l}22 \% \\
\text { (educational attainment } \\
\text { for the pop over } 25 \text { ) } \\
\text { etween } Y \text { per worker in the } \\
\text { er worker in } 1988 \text { and the } \\
\text { the former was } 32 \text { times }\end{array}$ & $\begin{array}{l}\text { Imposed: } \\
\text { for } K=0.3 \\
\text { for } H \text {, piecewise linear } \\
\text { in years of education: } \\
\quad=13.4 \text { for } 1-4 \text { years } \\
\quad=10.1 \text { for } 5-8 \text { years } \\
\quad=6.8 \text { for over } 8 \text { years }\end{array}$ \\
\hline
\end{tabular}

(continued) 
Table 1. Continued.

\begin{tabular}{|c|c|c|c|c|c|}
\hline & $\mathrm{Y}$ & A & & $X$ & \\
\hline & Output & TFP & $\begin{array}{c}\text { K } \\
\text { Physical capital }\end{array}$ & $\begin{array}{c}\mathrm{H} \\
\text { Human capital }\end{array}$ & Elasticities \\
\hline & $\begin{array}{l}\text { For the average } \\
\text { country vis-à-vis US: } \\
0.29\end{array}$ & 0.52 & 0.85 & $\begin{array}{l}0.57 \\
\text { Average country has } \\
57 \% \text { of US } H \text { per } \\
\text { worker and } 29 \% \text { of US } \\
Y \text { per worker; if } H \text { per } \\
\text { worker were increased } \\
\text { by } 75 \% \text { (so that no dif- } \\
\text { ferences in } H \text { per worker } \\
\text { is left), } Y \text { per worker } \\
\text { would be increased by } \\
47 \% \text { (reaching } 44 \% \text { of } \\
\text { US } Y \text { per worker). Thus } \\
\text { a } 1 \% \text { increase in } H \text { per } \\
\text { worker leads to a } 0.6 \% \\
\text { increase in } Y \text { per worker. }\end{array}$ & \\
\hline \multirow[t]{2}{*}{$\begin{array}{l}\text { Klenow- } \\
\text { Rodriquez } \\
(1997) \\
\rightarrow \mathbf{A}\end{array}$} & $\begin{array}{l}\text { Level accounting: cross- } \\
\text { country differences in } \\
\text { output per worker, } 98 \\
\text { countries in } 1985\end{array}$ & $67 \%$ & $29 \%$ & $\begin{array}{l}4 \% \\
\text { If } 1 \% \text { higher } Y \text { per } \\
\text { capita (than the average } \\
\text { country), expect } 0.04 \% \\
\text { higher } H \text { per capita }\end{array}$ & $\begin{array}{l}\text { Imputed according } \\
\text { to Mankiw et al. }(1992) \\
\text { For } K=0.30 \\
\text { For } H=0.28\end{array}$ \\
\hline & $\begin{array}{l}\text { Growth accounting: cross- } \\
\text { country differences in } \\
\text { 1960-85 growth in output } \\
\text { per worker, } 98 \text { countries }\end{array}$ & $85-90 \%$ & $3 \%$ & $6-12 \%$ & \\
\hline
\end{tabular}


(i.e. account is taken of changes in the age, sex and educational composition of the workforce, as well as of hours of work).

Finally, as argued in Section 2.3, 'accounting is no explanation'. Apportioning income or income growth to measured and unmeasured 'inputs' provides no insight as to the mechanisms which may underlie such contributions. And as to those studies showing the overwhelming importance of total factor productivity, results need to be further explored as to examine the fundamental sources of such a factor. The study by Hall and Jones (1999) is a promising attempt in this direction (more on this in Section 4.3.5).

\subsubsection{Macro Growth Regressions}

Cross-country growth regressions are (in contrast to growth or level accounting) more focussed on identifying the sources of economic growth and in actually quantifying such correlations. Ideally, the aim would be to assess the causal impact of, say, average years of education or school enrolment rates on a country's rate of income growth.

Even within this approach, however, the various estimates are not directly comparable, due to:

\section{Different dependent variables}

Although most studies focus on explaining cross-country differences in real per capita GDP growth rates, other choices include: overall real GDP growth rates, growth of labour productivity or of total factor productivity and the log of the ratio of real (per capita or overall) GDP in two periods. Mankiw, Romer and Weil's (1992) work should not actually be counted among 'growth' regressions, since it centres around cross-country differences in levels (more precisely, in the log of GDP per capita).

2. Different human capital regressors

A first fundamental difference is between studies that consider the impact of the level (stock) of human capital and those looking at the flow of (investment in) human capital. The former tend to use average years of education in the labour force, and the latter school enrolment rates, although Gemmel (1996) shows that school enrolment rates confound the effects of human capital stock and accumulation. Some authors have instead developed and constructed their own measures of human capital stocks and flows. These independently constructed measures have the advantage of possibly overcoming some of the shortcomings of commonly used proxies, at the cost however of not being particularly transparent, thus lacking immediate policy interpretation.

Secondly, both stocks and flows have been considered by different studies either at the primary, secondary and/or tertiary levels, so that various estimates more often than not relate to a different level of education.

\section{Different samples}

Most studies integrate developing and developed countries in a single framework, while some focus on OECD countries only, and some others split their samples into sub-samples according to the countries' level of development. The studies using two (or three) sub-samples have found that the impacts of human capital flow and stock - both of which considered at the primary, secondary 
and tertiary level - vary considerably, both in statistical significance and in magnitude, according to the level of development of the countries considered. All this makes it extremely hazardous to try to lump estimates on such more restricted samples with those representing an average over more diverse countries.

This discussion should have made it clear that it would not be particularly sensible, if at all possible, to try and force all the estimates on a common basis.

Instead, Table 2 contrasts the various studies, highlighting the dependent variable analysed, the schooling regressor used, if the study was meant to capture the flow or the level of human capital, the estimated coefficient as reported in the paper and an interpretation of the implied impact. The sample combines developed and developing countries if not otherwise specified. Where provided in the papers, the mean of the human capital proxy is reported.

It is important to understand that the main aim of such studies is to identify statistically significant and possibly robust relationships between various factors and economic growth. Ideally, such estimates should reflect, through appropriate methodologies, not simple statistical correlations, but causal relationships and thus identify sources of economic growth. In practice, it is still debatable if such a result has been actually achieved (cf. Section 3, in particular 3.2).

The authors are thus satisfied with showing that a variable shows a significant correlation to growth (i.e. that such correlation is statistically different from zero) and to compare the relative impact, statistical significance and robustness of this variable. Robustness is defined implicitly as a relationship that remains significant and of the same sign when including different sets of other regressors, or using slightly different data, samples or methodologies. The main message the authors seek to convey to the reader is that a given factor does indeed positively — or negatively — affect growth, and is more - or less - important than another. Methodological and especially data constraints seem to severely hinder a precise numerical quantification of the effects, so that the actual magnitude of the estimated effect is almost invariably ignored. The most notable exception among the studies surveyed is Barro (1997), who actually states that 'on impact, an extra year of male upper-level schooling is therefore estimated to raise the growth rate by a substantial 1.2 percentage points per year' (p.19).

For ease of interpretation and comparisons, the 'Interpretation of Impact' column of Table 2 tries to replicate a statement along these lines for all the studies reviewed. To ease the 'visualisation' of what the estimates imply in monetary terms, Section 4.2 simulates the impact on national output of a reform increasing the human capital stock in an economy similar to the UK. We use a number of estimates that are in the range of those found in the studies summarised in Table 2.

Still the reader is advised to keep the above-mentioned caveat in mind; by far the most reliable results are those expressed in qualitative terms (see also Section 4.3).

\subsubsection{Stages, Levels and Types of Education}

Ideally, the macro regressions would also look at education in a more disaggregated way and provide information regarding the growth impact of the various stages, levels and types of education, as well as on their interactions.

(C) Blackwell Publishing Ltd. 2003 
Table 2. Cross-Country Growth Regressions.

\begin{tabular}{|c|c|c|c|c|c|}
\hline Study & Dependent Variable & Human Capital Proxy & Flow/Stock & Estimated Coefficient & Illustration of Impact \\
\hline Barro (1991) & $\begin{array}{l}\text { growth rate of real } \\
\text { per capita GDP } \\
\text { annual } 1960-85\end{array}$ & $\begin{array}{l}\text { school enrolment rate: } \\
\text { number of students } \\
\text { enrolled in the designated } \\
\text { grade levels (primary and } \\
\text { secondary respectively) } \\
\text { relative to the total } \\
\text { population of the corres- } \\
\text { ponding age group in } 1960\end{array}$ & $\begin{array}{l}\text { initial flow } \\
\text { mean: } \\
\text { prim60: } 0.78 \\
\text { sec60: } 0.23\end{array}$ & $\begin{array}{l}\text { prim }=0.025 \\
\text { sec }=0.030\end{array}$ & $\begin{array}{l}\text { A } 1 \text { percentage point } \\
\text { increase in primary } \\
\text { (secondary) school } \\
\text { enrolment rates is } \\
\text { associated with a } 2.5 \\
\text { (3.0) percentage points } \\
\text { increase in per capita } \\
\text { GDP growth rate. }\end{array}$ \\
\hline $\begin{array}{l}\text { Levine and } \\
\text { Renelt (1992) }\end{array}$ & $\begin{array}{l}\text { growth rate of real } \\
\text { per capita GDP } \\
\text { annual } \\
1960-89\end{array}$ & $\begin{array}{l}\text { secondary school enrol- } \\
\text { ment rate in } 1960\end{array}$ & initial flow & $\begin{array}{l}\text { high }=3.71 \\
\text { base }=3.17 \\
\text { low }=2.5\end{array}$ & $\begin{array}{l}\text { A } 1 \text { percentage point } \\
\text { increase in secondary } \\
\text { school enrolment rate } \\
\text { is associated with a } \\
\text { between } 2.5 \text { and } 3.7 \\
\text { percentage points } \\
\text { increase in per capita } \\
\text { GDP growth rate. }\end{array}$ \\
\hline $\begin{array}{l}\text { Murphy, } \\
\text { Schleifer and } \\
\text { Vishny (1991) }\end{array}$ & $\begin{array}{l}\text { growth rate of real } \\
\text { per capita GDP } \\
\text { between } 1970-85\end{array}$ & $\begin{array}{l}\text { primary school enrol- } \\
\text { ment rate in } 1960\end{array}$ & initial flow & $\begin{array}{l}\text { full sample: } \\
0.022 \\
\text { (OECD: not } \\
\text { significant) }\end{array}$ & $\begin{array}{l}\text { A } 1 \text { percentage point } \\
\text { increase in primary } \\
\text { school enrolment rate } \\
\text { is associated with a } \\
2.2 \text { percentage points } \\
\text { increase in per capita } \\
\text { GDP growth rate. }\end{array}$ \\
\hline Barro (1997) & $\begin{array}{l}\text { growth rate of real } \\
\text { per capita GDP } \\
\text { over } 1965-75, \\
1975-85 \text {, } \\
1985-90\end{array}$ & $\begin{array}{l}\text { average years of attain- } \\
\text { ment for males aged } 25 \\
\text { and over in secondary } \\
\text { and higher schools at } \\
\text { the start of each period }\end{array}$ & $\begin{array}{l}\text { initial stocks in } \\
1965,75 \text { and } 85 \\
\text { mean in } 1990= \\
1.9 \text { years }\end{array}$ & 0.012 & $\begin{array}{l}\text { An extra year of male } \\
\text { upper-level schooling } \\
\text { is associated with a } \\
1.2 \text { percentage point } \\
\text { increase in per capita } \\
\text { GDP growth rate. }\end{array}$ \\
\hline
\end{tabular}


Table 2. Continued.

\begin{tabular}{|c|c|c|c|c|c|}
\hline Study & Dependent Variable & Human Capital Proxy & Flow/Stock & Estimated Coefficient & Illustration of Impact \\
\hline $\begin{array}{l}\text { Hanushek } \\
\text { and Kim (1995) }\end{array}$ & $\begin{array}{l}\text { growth rate of real } \\
\text { per capita GDP } \\
\text { between } 60-90\end{array}$ & $\begin{array}{l}\text { average years of secondary } \\
\text { schooling of adult male } \\
\text { population at beginning } \\
\text { of period }\end{array}$ & initial stock & 0.36 & $\begin{array}{l}\text { An extra year of male } \\
\text { secondary schooling is } \\
\text { associated with a } 0.36 \\
\text { percentage point increase } \\
\text { in per capita GDP } \\
\text { growth rate. }\end{array}$ \\
\hline Gemmel (1996) & $\begin{array}{l}\text { growth rate of } \\
\text { real per capita GDP } \\
\text { annual } 60-85\end{array}$ & $\begin{array}{l}\text { constructed human capital } \\
\text { stock in } 1960 \text { and human } \\
\text { capital annual average } \\
\text { growth rates at primary, } \\
\text { secondary and tertiary } \\
\text { levels. } \\
\text { These measures are both } \\
\text { entered in the equation } \\
\text { simultaneously. }\end{array}$ & $\begin{array}{l}\text { initial stock } \\
\text { mean: } \\
\text { prim }=72.8 \\
\text { sec }=19.5 \\
\text { tert }=4.0 \\
\text { annual flows } \\
\text { mean: } \\
\text { prim }=2.5 \\
\text { sec }=3.7 \\
\text { tert }=2.7\end{array}$ & $\begin{array}{l}\text { Full sample: } \\
\text { prim stock }=0.81 \\
\text { prim flow }=2.68 \\
\text { Poorest LDCs: } \\
\text { prim stock }=0.91 \\
\text { prim flow }=4.19 \\
\text { Intermediate LDCs: } \\
\text { sec stock }=1.09 \\
\text { OECD: } \\
\text { tert stock }=1.10 \\
\text { tert flow }=5.89\end{array}$ & $\begin{array}{l}\text { For OECD: } \\
\text { A } 1 \text { percent increase } \\
\text { in tertiary human } \\
\text { capital stock is } \\
\text { associated with a } 1.1 \\
\text { percentage point } \\
\text { increase in per capita } \\
\text { GDP growth rate. } \\
\text { A } 1 \text { percentage point } \\
\text { increase in tertiary } \\
\text { human capital growth } \\
\text { is associated with a } \\
5.9 \text { percentage points } \\
\text { increase in per capita } \\
\text { GDP growth rate. }\end{array}$ \\
\hline Judson (1998) & $\begin{array}{l}\text { growth rate of real } \\
\text { GDP } \\
\text { 5-years averages, } \\
1960-90\end{array}$ & $\begin{array}{l}\text { growth of her constructed } \\
\text { measure of human capital } \\
\text { stock }\end{array}$ & period flows & $\begin{array}{l}10.8 \\
\text { low-efficiency } \\
\text { countries } \\
=3.0 \\
\text { high-efficiency } \\
=12.9\end{array}$ & $\begin{array}{l}\text { A } 1 \text { percentage point } \\
\text { increase in human } \\
\text { capital growth is } \\
\text { associated with an } \\
11 \text { percentage points } \\
\text { increase in GDP } \\
\text { growth rate. }\end{array}$ \\
\hline
\end{tabular}




\begin{tabular}{|c|c|c|c|c|c|}
\hline $\begin{array}{l}\text { Englander and } \\
\text { Gurney (1994) }\end{array}$ & $\begin{array}{l}\text { growth of labour } \\
\text { productivity (and } \\
\text { total factor } \\
\text { productivity) over } \\
\text { four time periods }\end{array}$ & $\begin{array}{l}\text { school enrolment rates: } \\
\text { number of students } \\
\text { enrolled in secondary } \\
\text { school relative to the } \\
\text { total population of the } \\
\text { corresponding age group } \\
\text { in beginning of period }\end{array}$ & initial flow & $\begin{array}{l}\text { OECD: } \\
1.45-1.78\end{array}$ & $\begin{array}{l}\text { A } 1 \text { percentage point } \\
\text { increase in secondary } \\
\text { school enrolment rate } \\
\text { is associated with } \\
\text { around } 1.5 \text { percentage } \\
\text { point increase in } \\
\text { productivity growth. }\end{array}$ \\
\hline $\begin{array}{l}\text { Barro and Lee } \\
(1994)\end{array}$ & $\begin{array}{l}\Delta \operatorname{lnGDP} \\
\text { per worker }\end{array}$ & $\begin{array}{l}\text { average years of } \\
\text { secondary schooling of } \\
\text { adult male population } \\
\text { at beginning of period }\end{array}$ & initial stock & 0.014 & $\begin{array}{l}\text { An extra year of male } \\
\text { secondary schooling is } \\
\text { associated with a } \\
1.4 \text { percent increase in } \\
\text { per worker GDP growth. }\end{array}$ \\
\hline $\begin{array}{l}\text { Benhabib and } \\
\text { Spiegel (1994) }\end{array}$ & $\Delta \operatorname{lnGDP}$ per capita & $\begin{array}{l}\text { human capital stock } \\
\text { estimates from Kyriacou: } \\
\text { average level of log human } \\
\text { capital over the period } \\
\text { (log of average level of } \\
\text { human capital; } \\
\text { log of average levels) }\end{array}$ & average stock & $0.12-0.17$ & $\begin{array}{l}\text { A } 1 \text { percent increase in } \\
\text { the stock of human } \\
\text { capital is associated } \\
\text { with a } 12 \text { to } 17 \text { percent } \\
\text { increase in per capita } \\
\text { GDP growth. }\end{array}$ \\
\hline $\begin{array}{l}\text { Mankiw, } \\
\text { Romer } \\
\text { and Weil } \\
(1992)\end{array}$ & $\begin{array}{l}\text { lnGDP per } \\
\text { working-age } \\
\text { person }\end{array}$ & $\begin{array}{l}\text { average percentage of } \\
\text { working-age population in } \\
\text { secondary school, } 1960-85\end{array}$ & period flow & $\begin{array}{l}\text { implied output } \\
\text { elasticity with } \\
\text { respect to human } \\
\text { capital stock }=0.28\end{array}$ & $\begin{array}{l}\text { A } 1 \text { percent increase in } \\
\text { the average percentage } \\
\text { of working-age popu- } \\
\text { lation in secondary } \\
\text { school is associated } \\
\text { with a } 0.66 \text { percent } \\
\text { increase in GDP per } \\
\text { working-age person. } \\
\text { A } 1 \text { percent increase } \\
\text { in human capital stock } \\
\text { is associated with a } 0.28 \\
\text { percent increase in GDP }\end{array}$ \\
\hline
\end{tabular}


Table 2. Continued.

\begin{tabular}{|c|c|c|c|c|c|}
\hline Study & Dependent Variable & Human Capital Proxy & Flow/Stock & Estimated Coefficient & Illustration of Impact \\
\hline $\begin{array}{l}\text { de la Fuente } \\
\text { and Doménech } \\
\text { (2000) }\end{array}$ & $\begin{array}{l}\text { GDP per worker } \\
\text { Annual, } \\
\text { 1960-90 } \\
\text { OECD }\end{array}$ & $\begin{array}{l}\text { average number of } \\
\text { years of schooling } \\
\text { of the adult } \\
\text { population }\end{array}$ & $\begin{array}{l}\text { stock } \\
\text { mean ' } 90=10.49 \\
\left(\mathrm{UK}^{\prime} 90=10.94\right)\end{array}$ & $\begin{array}{l}\text { implied output } \\
\text { elasticity with } \\
\text { respect to human } \\
\text { capital stock }=0.27\end{array}$ & $\begin{array}{l}\text { A } 1 \text { percent increase in } \\
\text { human capital stock is } \\
\text { associated with a } 0.27 \\
\text { percent increase in GDP. } \\
\text { At the sample mean, an } \\
\text { increase in average } \\
\text { education by one year } \\
\text { would raise output per } \\
\text { capita by ca. } 3 \text { percent. }\end{array}$ \\
\hline $\begin{array}{l}\text { Bassanini and } \\
\text { Scarpetta } \\
\text { (2001) }\end{array}$ & $\begin{array}{l}\text { GDP per } \\
\text { working-age } \\
\text { person } \\
\text { Annual, 1971-98 } \\
\text { OECD }\end{array}$ & $\begin{array}{l}\text { average number of } \\
\text { years of schooling } \\
\text { of the adult } \\
\text { population }\end{array}$ & $\begin{array}{l}\text { stock } \\
\text { mean }=10.15\end{array}$ & $\begin{array}{l}\text { implied output } \\
\text { elasticity with } \\
\text { respect to human } \\
\text { capital stock }=0.57\end{array}$ & $\begin{array}{l}\text { A } 1 \text { percent increase in } \\
\text { human capital stock is } \\
\text { associated with a } 0.57 \\
\text { percent increase in GDP. } \\
\text { At the sample mean, an } \\
\text { increase in average } \\
\text { education by one year } \\
\text { would raise output per } \\
\text { capita by ca. } 6 \text { percent. }\end{array}$ \\
\hline
\end{tabular}

Notes: For details on the individual studies, see the appendix available on www.ifs.org.uk/workingpapers/wp0205.pdf. 
In particular, the answer to the following questions would provide extremely valuable information for the policy-maker:

(a) stages of education: what are the relative growth returns of pre-school, primary, secondary and higher education, with important implications for how resources should be divided between the different stages of education;

(b) levels: are there decreasing returns to additional years of schooling; does the impact of expanding a stage of education (say, higher education) depend on the initial levels of attainment in that stage;

(c) types of education: what is the impact on growth of e.g. vocational versus academic education;

(d) interactions between stages: does the impact of expanding a stage of education (say, post-compulsory schooling) depend on the initial levels of attainment in the previous stage (compulsory education).

Unfortunately, the available literature is still only tentatively and marginally able to provide reliable findings that could shed some light on such relevant issues.

The major constraint appears to be the inappropriateness of the macro data. Such questions have been successfully addressed at the individual level by microeconometric studies, able to exploit huge data sets with a large amount of detailed individual information.

As to the macro data requirements, one would ideally look at the country of interest, say the UK, using a very long time series of observations on economic growth. The relevant factors would include averages of the various stages, levels and types of education in the population, and allow for non-linearities and interactions in the estimation, while properly controlling for endogeneity. It is clear that to date time series sufficiently long to allow precise estimates of such sophisticated models are not available. The study by Jenkins (1995), for instance, is a promising first step, using time series data for the UK from 1971 to 1992. Still, the size of her time series sample ( 22 observations) means that her estimates are imprecisely determined and difficult to draw conclusions from.

The second-best 'solution' adopted by most of the macro studies is to increase the sample size by using cross-country information. Such samples include countries at very disparate stages of development, which carries with it the limitation (in addition to the implicit restriction of homogeneous effects) that the variables and thus questions - analysed have to be restricted to the smallest common denominator. It has proven already difficult to construct roughly comparable indicators of years of education and school enrolment rates across all countries, the only disaggregation reached consisting in primary and secondary schooling. Most less developed countries lack (reliable) data on tertiary, let alone pre-school education or specific types of education.

Having explained why the information relating to the above questions is disappointingly scarce and fragile, the following can be derived from the available evidence. To our knowledge, question (d) has not been tackled in the macro literature. 
(a) stages of education

$$
\text { -Effect of pre-school — or pre-compulsory — education on economic growth }
$$

There are some micro-econometric studies addressing the impact of pre-school education on various labour market as well as social indicators at the individual level (e.g. Head Start, for a review see Currie, 2001). At the macro level, however, the evidence on this issue is, to our knowledge, completely absent.

-Effect of primary education on economic growth

For the full sample of countries, a one percentage point increase in primary school enrolment rates is estimated to lead to a two percentage points increase in the per capita GDP growth rate, while the same increase in the stock of primary human capital would lead to less than one percentage point increase in the growth rate. Both types of impact are larger for the sub-sample of the poorest developing countries, while not considered in the regressions for OECD countries (there would not be enough variability within this more homogenous sample of advanced economies).

- Effect of secondary education on economic growth

A one percentage point increase in secondary school enrolment rates is shown to lead to a 2.5-3 percentage points increase in growth in the full sample, the effect being smaller (around 1.5 or even zero) for OECD countries. As to the stock, an additional year of education seems to lead to a $0.5-1.2$ percentage points faster growth, again with no impact for OECD countries.

-Effect of tertiary education on economic growth

The main study considered here is Gemmel (1996). He finds evidence for endogenous growth in the sense that there is an effect of the 1960 level of schooling on growth even after conditioning on the 1960-85 growth rate of human capital. For OECD countries, a one percentage point increase in the annual growth of human capital increases growth by 5.9 percentage points. ${ }^{5}$ Conditional on this growth, a one percent increase in the initial human capital stock contributes to a 1.1 percentage points increase in growth. ${ }^{6}$ Tertiary education was not included in the non-OECD countries regressions because of limited availability and reliability of such data.

\section{(b) levels of education and decreasing returns}

The main reference concerning this issue is Krueger and Lindahl (1998), who explicitly consider the robustness of the traditional macro regressions to various assumptions implicitly relied upon, among which the one that the effect of education on growth is linear (cf. Section 3.5). They find these restrictions rejected by the data, which seem to prefer a quadratic specification, with an inverted-U shaped relationship between the stock of human capital and economic growth. Even more interesting, they find the peak at 7.5 years of education to be below the average 1990 OECD education level of 8.4. The finding that the average OECD country is consistently found to be on the downward-sloping portion of the education-growth profile, 'casts doubt on the likelihood that there are large growth externalities from the initial level of education, especially in OECD countries' (p. 38). If their results were taken literally, the quoted statement 
would need to be taken further, since the findings imply the uncomfortable presence of negative growth returns of further expansion in education in developed countries.

\section{(c) types of education}

One study which has tried to investigate if the allocation of students to different types of education matters for growth, is Murphy, Schleifer and Vishny (1991). For the sub-sample of countries with a large student population (over 10,000 college students), they find that the relative importance of engineering in education (as captured by the ratio of college enrolments in engineering to total college enrolments) has a positive impact on growth, while the relative importance of legal studies has a negative effect. It has to be said, however, that these results, based on such a small sample, are hardly reliable; in fact, the former effect is not statistically significant, while the latter just borders significance.

\subsubsection{OECD Countries}

It may be helpful to summarise the main findings relating to the more homogeneous sub-sample of OECD countries which have quite consistently arisen in the empirical literature.

First of all, the regressors that appear to have an important impact on growth in samples including both OECD and developing countries have traditionally been found to be considerably less precise and to have much less explanatory power when estimated for the OECD sub-sample alone (cf. e.g. Mankiw, Romer and Weil, 1992, Englander and Gurney, 1994 and Gemmel, 1996).

The smaller sample size as well as its more homogeneous nature are likely to explain the difficulty of identifying precise individual effects ${ }^{7}$; in any case, care needs to be taken when extending inferences drawn from the wider sample to a particular high-income economy.

Some promising recent developments relate to the use of a new harmonised dataset providing reliable information on years of education for the OECD. Using national data sources, de la Fuente and Doménech (2000) compile a revised version of the Barro-Lee database by removing time and cross-country inconsistencies. The resulting database is then further extended forward in time to 1998 by Bassanini and Scarpetta (2001).

Despite the cross-country variability in both growth and education being much smaller when focusing on the OECD sample, both studies exploit the new dataset as well as the time-series dimension of the data to obtain significant and robust estimates.

In both level and growth equations, as well as when modelling technological catch-up and controlling for fixed period and country effects (a specification explaining $80 \%$ of the variation in the growth rate of productivity), de la Fuente and Doménech (2000) find a strongly significant and robust coefficient for educational attainment - implying an elasticity of output per capita to additional years of schooling of 0.27 . 
Similarly, Bassanini and Scarpetta (2001) estimate an elasticity of output per capita to additional years of schooling of 0.57 using a method (the pooled mean group estimator) that allows the short-run dynamics to be country-specific. At the sample mean of 10 years of average education, this latter estimate implies that increasing average education by one year would raise output per capita by 6 per cent, a macro return very much in line with the one estimated at the individual level (cf. 2.8).

\subsection{Some Quantitative Effects to Illustrate the Approaches}

As it should have now become apparent, reconciling the quantitative implications of the studies we survey is no easy task. Nevertheless it is useful to have some numbers to fix ideas of how large the effects are.

In order to get a feel of what magnitude of effects on output the estimates imply, we first outline the core of the econometric models used by the two approaches - the augmented neo-classical and the new growth approach.

We then simulate the impact on national output of a reform increasing the human capital stock in an economy with the basic features of the UK, using a number of estimates which are in the range of those found in major studies.

First, consider the augmented neo-classical model. Here human capital enters as another factor of production. In the Mankiw, Romer and Weil (1992) paper, for example, the production function is estimated to be constant returns CobbDouglas of the form:

$$
Y(t)=A(t) H(t)^{\alpha} L(t)^{\beta} K(t)^{1-\alpha-\beta}
$$

where $Y(t)$ is output at time $t, A$ the level of technology, $H$ the human capital stock in the labour force (say, total years of schooling), $L$ the labour force and $K$ the physical capital stock.

Dividing by $L$ and expressing all the variables in per capita terms (denoting them with the corresponding lower-case letter) yields:

$$
y(t)=A(t) h(t)^{\alpha} k(t)^{1-\alpha-\beta}
$$

where in particular $h \equiv H / L$ is the stock of human capital per worker (say, average years of schooling in the labour force).

In Mankiw, Romer and Weil (1992) $\alpha$ is econometrically estimated to be about one third. In their study, $h$ is implicitly proxied by average years of secondary schooling. Thus, doubling average years of attainment in secondary schooling in the population increases output per capital (productivity) by one third.

We call this a levels specification because the level of (per capita) human capital (h) affects the level of (per capita) productivity $(y)$.

By contrast a productivity growth model (as in Barro, 1997) has something like

$$
\frac{y(t)-y(t-1)}{y(t)}=\beta h(t)+\ldots
$$

(C) Blackwell Publishing Ltd. 2003 
where the left hand side variable is the growth rate of income per capita $(y \equiv Y / L)$ and $h$ is again human capital per capita.

Denoting the stock of human capital per capita at time 0 as $h_{0}$, rearranging and moving to continuous time, yields:

$$
y(t)=y_{0} e^{\beta h_{0} t}
$$

Note that by construction, in both approaches the returns to increases in human capital are linear, with $x$ years of extra education having $x$ times the impact of one extra year of education.

Suppose now that at time $t=0$ a reform is implemented, which at time $T$ increases human capital by $m$ years, so that at $t=T, h_{T}=h_{0}+m$.

In particular, consider an experiment that increases the average human capital stock by increasing secondary and higher schooling by one month for the population in an economy like the UK's, where average post-primary schooling is about 5.6 years (taken from the 1996/7 Family Resources Survey). This corresponds to an increase of $m=0.083$ years. $^{8}$ Initial income per capita $y_{0}$ is set to $£ 25,000$, with a labour force of 30 million.

In Table 3 the 'coefficient on human capital' in column (1) is $\alpha$ for the 'levels' specification in the upper panel and $\beta$ for the 'growth' specification in the lower panel.

We simulate the effect of this reform under three different parameter values of $\alpha$ and $\beta$ which encompass most of the central estimates in the literature. In order to have a common basis, the values chosen are from studies which use the same measure of the human capital stock - average years of (male) secondary (and higher) schooling in the population. For the levels specification, we are able to use some estimates recently obtained for the OECD sub-sample. This unfortunately is not the case for the growth specification ${ }^{9}$, for which it has thus to be kept in mind that the parameters used as the basis for the simulations have been estimated from samples including quite diverse types of countries (in particular a large number of developing countries), so that the additional caveats concerning parameter heterogeneity apply (cf. Section 3.3).

Two main types of simulations are performed:

1. in the first one (columns (2) and (3)), it is assumed that the adjustment to the new average level of human capital is immediate, and the corresponding steady states are compared.

2. in the second one (columns (4) to (7)), it is more realistically assumed that the adjustment works through an increase in the flow of human capital, so that the human capital stock only gradually and linearly increases from $h_{0}$ to $h_{0}+m$ over a period 40 years, where each year an increase of $m / 40$ is achieved.

It is important to note that in this exercise we assume that the reform takes place ceteris paribus, i.e. that only human capital is increased, while all other relevant variables remain constant. To clarify the implications, let $y^{1}(t)$ denote income at 
Table 3. Experiment: Increase human capital stock by one month.

(average years of male upper-level schooling in the population rise from 5.6 years to 5.6 years and one month)

\begin{tabular}{|c|c|c|c|c|c|c|}
\hline (1) & $(2)$ & (3) & (4) & $(5)$ & (6) & (7) \\
\hline \multirow{2}{*}{$\begin{array}{l}\text { Coefficient } \\
\text { on human } \\
\text { capital }\end{array}$} & \multirow{2}{*}{$\begin{array}{c}\text { Steady-state } \\
\text { change } \\
\text { in GDP per capita } \\
\text { (f) }\end{array}$} & \multirow{2}{*}{$\begin{array}{l}\text { Steady-state } \\
\text { change } \\
\text { in GDP } \\
(£ b n)\end{array}$} & \multicolumn{4}{|c|}{ Change in Present Value (£bn) } \\
\hline & & & 4 years & 40 years & 60 years & infinite horizon \\
\hline \multicolumn{7}{|c|}{ Levels Specification } \\
\hline 0.27 (DD) & 99.9 & 3.0 & 0.51 & 14.4 & 17.6 & 19.0 \\
\hline 0.37 (MRW) & 137.0 & 4.1 & 0.71 & 19.8 & 24.1 & 26.0 \\
\hline $0.57(\mathrm{BS})$ & 211.4 & 6.3 & 1.09 & 30.5 & 37.2 & 40.1 \\
\hline \multicolumn{7}{|c|}{ Growth Specification } \\
\hline 0.003 & 6.4 & 0.2 & 0.09 & 29.2 & 60.0 & 78.3 \\
\hline 0.01 & 22.0 & 0.7 & 0.33 & 298.7 & 820.1 & 25,940 \\
\hline 0.015 & 34.0 & 1.0 & 0.54 & $1,061.2$ & $4,358.8$ & $3.9 * 10^{9}$ \\
\hline
\end{tabular}

Notes:

1. $\mathrm{DD}=$ de la Fuente and Doménech (2000) for OECD sample; MRW= Mankiw, Romer and Weil (1992) for OECD sub-sample; BS = Bassanini and Scarpetta (2001) for OECD sample.

2. In levels specification, column (1) is the elasticity of output to human capital stock in a Cobb-Douglas production function.

3. In growth specification, column (1) is the coefficient on human capital stock in a Barro-style growth equation.

4. Columns (2) and (3) assume that the increase in human capital is immediate (i.e. stock not flow), so that the economy immediately jumps to its new steady state.

5. Columns (4)-(7) are the cumulated present value of output over the respective horizon assuming a social discount rate of $6 \%$ and that it takes 40 years to linearly adjust to the new steady state.

6. We assume that there are 30 million in the labour force (per capita is per member of labour force), and that per capita initial income is $£ 25,000$. 
time $t$ in the presence of the reform and $y^{0}(t)$ the counterfactual income at time $t$ (i.e. the level of income the economy would have achieved in the absence of the reform). For the level approach the ceteris paribus assumption implies that growth in the absence of the reform is zero, so that the counterfactual $y^{0}(t)$ remains in fact constant and equal to $y_{0}$, the initial income per capita. By contrast, for the growth specification, even in the absence of the reform the economy enjoys a positive growth rate, since, by construction, the growth rate is a positive function of the present level of human capital $h_{0}$. In other words, unless the pre-reform human capital stock is zero, the economy would grow even in the absence of the reform, as can be seen from the explicit time-dependence of the counterfactual $y^{0}(t)=y_{0} e^{\beta h_{0} t}$. The gains from the reform presented in Table 3 are always calculated with respect to the counterfactual of a growing economy $y^{0}(t)$, whereas for the levels specification this is equal to initial income per capita 25,000 for all $t$.

Also note that the present value calculations (all based on a social discount rate of $6 \%$ ) are not net present value gains, but only concern the benefit side; no account is taken of the costs to achieve - and maintain - the higher human capital stock. In fact, average human capital in the population has not only to be increased by one month, but has then to be kept at this higher level forever, which means that all cohorts graduating from school have to have remained in secondary school for one month longer on average.

Turning to the first type of simulation (immediate adjustment), for the levels specification the policy experiment is seen to generate an increase in GDP by between $£ 100$ and $£ 200$ per capita. For an economy similar in size to that of the UK (c. $30 \mathrm{~m}$ in labour force, $£ 750$ bn GDP) this generates an increase of GDP of $£ 3-6$ bn. By contrast, for the growth specification, the one-off gain is considerably lower, between $£ 0.2$ and 1 bn.

If we allow for the more realistic scenario of gradual adjustment to the new human capital stock, we again see that the gains in the first years of the reform are considerably lower for the growth specification (around half of the levels effect for the first four years). However, already by the time when the new stock of human capital has been attained (i.e. after 40 years), the situation has turned. The growth specification produces a discounted gain of between $£ 29$ bn and over $1,000 \mathrm{bn}$, while the levels specification yields a discounted cumulated increase in GDP of $£ 15-30 \mathrm{bn}$. From this moment onwards, the gap in gains from the two specifications widens massively.

In fact, in the levels specification the economy has returned to zero growth - albeit remaining at its larger size - , so that the constant gain is discount more and more heavily back to today; it stabilises around $£ 20-40$ bn, even over the infinite future.

By contrast, in the growth specification the economy continues to exponentially grow at the higher rate (for the three values of $\beta$, the economy grows at an incremental rate - i.e. vis-à-vis the no-reform scenario - of $0.3,1.1$ and 1.6 percentage points respectively). This massively increases the benefits of the intervention. Of course these numbers become huge - and even tiny differences in parameter values yield tremendous differences in cumulated gains - when discounting takes place over the infinite future. 
Interestingly, although the theories underlying the empirical specifications are very different, it appears that in magnitude the effects are not excessively different over the typical planning horizon of the government (four years).

Abandoning the shorter horizon, though, the implied effects of education on growth appear implausibly large in the standard Barro approach. We join Topel (1999) - 'the magnitude of the effect of education on growth is vastly too large to be interpreted as a causal force' - in finding it too hard to view such huge effects as uniquely the result of economy-wide externalities generated by the increase in average educational attainment.

Alternative explanations which cast doubts on the interpretation of such 'new growth' evidence as educational spill-overs include:

- reverse causality: cross-countries differences in education could be, in part at least, the result of anticipated economic growth ${ }^{10}$;

- omitted variable bias in cross-country analyses: countries that improve their education systems are likely to implement concomitant reforms and policies that enhance growth;

- other more technical reasons for a positive and significant coefficient of the stock of human capital in a growth regression ${ }^{11}$;

- some surprising findings - e.g. no or negative effect of female education at various levels, or no impact of male primary schooling in Barro (1997) — are left unexplained, and cast doubts as to the large significant effect found for male upper-level education only.

In addition, the checks by Krueger and Lindahl (1998) have shown how fragile the macro evidence of educational externalities is to relaxing the (data-rejected) restrictions of homogeneity and linearity of impact. In particular (cf. also Sections 3.3 and 3.5):

- The homogeneous-slope restriction is rejected by the data, and when estimating a variable-coefficient model the average initial human capital stock has an insignificant effect on growth. This finding casts doubts on the interpretation of such a coefficient in the macro regressions which commonly constrain their model to a constant education slope.

- Once relaxing the linearity assumption, the relationship between the stock of human capital and economic growth is found to be inverted-U shaped, peaking below the average OECD education level. The finding that the average OECD country is on the downward-sloping part of the educationgrowth profile (in all their specifications) raises doubts as to the existence of large educational externalities, especially for this group of countries.

In the light of this set of considerations, we too consider the estimates obtained by the Barro regressions likely to be partly flawed, with the implied simulated effects largely implausible.

The neo-classical approach, by contrast, generates effects that are both more reasonable on a priori grounds and more consistent with the micro-economic evidence. 


\subsection{Other Important Results in literature}

Overall, the available evidence agrees in finding a positive effect of education on growth. This section summarises other key research findings on the link between educational investments and economic growth.

\subsubsection{Heterogeneous Effects of Different Types of Education}

An important finding is that the impact of increases in various levels of education appears to vary according to the level of a country's development.

In particular, while primary and secondary skills appear to be related to growth in the poorest and in intermediate developing countries respectively, it is tertiary skills that are important for growth in OECD countries. Although the direction of causality is unclear (higher education is likely to have the largest consumption component and one may expect the demand for it to increase with rising income), both the initial level and the subsequent growth of tertiary education were found to be positively and significantly related to per capita income growth in OECD countries (e.g. Gemmel, 1996).

\subsubsection{Indirect Effects of Human Capital on Growth}

In addition to its direct impact on economic growth, human capital may also have an effect on other factors which affect growth, so that investments in education would have an additional indirect effect on economic performance. In particular, human capital may yield additional benefits to growth if it stimulates the accumulation of other productive inputs - e.g. physical capital, technology or health - which in turn foster growth, or if it discourages factors, like population growth or infant mortality, which hamper growth.

Using regression techniques similar to the ones aimed at identifying the determinants of economic growth, but with a different dependent variable, human capital has in fact consistently been found to have a positive indirect effect as well, via its impact on:

- physical investment

Human capital appears to be associated with significantly larger investments (e.g. Barro, 1991, Gemmel, 1996, Benhabib and Spiegel, 1994). For OECD countries in particular, the stock of secondary human capital appears particularly important in stimulating investments, while direct growth effects come through increased tertiary human capital stock and accumulation.

- technology transfer

Human capital displays a positive effect on rates of productivity growth by raising the rate at which leading-edge foreign technologies are adopted (e.g. Griffith, Redding and Van Reenen, 2000, Cameron, Proudman and Redding, 1998, Benhabib and Spiegel, 1994). 


\section{- fertility}

Human capital - in particular female education - appears to be associated with significantly lower net fertility and thus population growth (Barro, 1991, Barro and Lee, 1994).

- other dimensions of human capital

Educational attainment has been found to be associated with higher life expectancy, lower infant mortality and higher levels of primary and secondary school enrolment rates (Barro and Lee, 1994).

An interesting issue which is however completely ignored by the macro literature concerns the role of training in economic growth, and the connected relationship between the level of education and subsequent investments in human capital accumulation on the job. Standard human capital theory predicts that individuals with higher levels of education have a stronger incentive and are offered more opportunities to accumulate further human capital through on-the-job training. The micro literature, in addition to uncovering substantial individual wage returns from training, does in fact provide ample empirical support to the prediction that more highly educated individuals also enjoy enhanced work-related training later on in working life (for a discussion of the theory behind the education-training nexus and a review of the relevant empirical evidence, see Blundell, Dearden, Meghir and Sianesi, 1999).

\subsubsection{Quality of Schooling}

When assessing the impact of an additional year of education on economic performance, all cross-country regressions implicitly assume that one year of secondary schooling, say in the US, is equivalent to a year at the same grade in other countries (e.g. Egypt). Hanushek and Kim (1995) and Hanushek and Kimko (2000) by contrast recognise that pure quantity of education is only a very crude measure of skill differences, since school systems vary widely across countries in terms of resources, organisation, duration and the preparation of entering students. They thus try to adjust for differences in schooling quality by using direct measures of cognitive skills of individuals, often interpreted as a measure of schooling outcomes.

The basic conclusion is that accounting for differences in labour force quality - as measured by student cognitive performance in various international comparative tests of academic achievement — significantly improves our ability to explain growth rates. Furthermore, labour force quality has a robust and strong influence on economic growth; even though some uncertainty remains as to the actual magnitude of the growth effect of labour force quality, the additional investigations by Hanushek and Kimko (2000) highlight the causal nature of the impact of this dimension of human capital on economic growth. In addition, the marginal effect of quality appears to decline with an increase in the overall level of education in the population, and, similarly, the additional impact of one year of education is a decreasing function of the quality level. Finally, and most

\footnotetext{
(C) Blackwell Publishing Ltd. 2003
} 
importantly in terms of the evaluation of those macro regressions ignoring quality issues, controlling for labour force quality considerably reduces the magnitude of the measured impact of years of schooling on growth.

\subsubsection{Allocation}

Macro regressions investigating the role of education for economic growth also typically ignore how educational resources are allocated.

A study by Judson (1998), however, provides evidence that more than the level of educational investment, it is its allocation that matters for economic growth.

The efficiency of the allocation of educational spending between primary, secondary and tertiary education chosen by several countries - including less developed ones - between 1970 and 1990 is evaluated on the basis of a micro theoretical model of returns to education. Efficiency is defined as the ratio of the achieved rate of return to the maximum possible rate of return the country could obtain given its actual overall education budget and actual relative costs for each level of education. She finds that despite the fact that for many countries there is a considerable gap between actual and optimal enrolment rates, several economies seem to be allocating their educational resources in a nearly optimal way (most allocations yield at least $80 \%$ of the optimal rate of return).

She then turns to testing whether her constructed measure of efficiency in the allocation of educational resources impacts on how education itself affects growth, finding that the contribution of human capital to growth does indeed depend on the efficiency with which it is being accumulated. Those countries that have been identified as allocating their educational resources inefficiently gain little from their investments in human capital in terms of growth. Despite some potential difficulties with her methodology, these results have important policy implications in terms of the importance of the allocation of educational resources.

Similarly (but on the basis of fragile results), Murphy, Schleifer and Vishny (1991) find that it is not just the quantity human capital, but also how this talent is allocated - to productive and innovative $v s$. rent-seeking activities - that may matter for growth (cf. 4.1.3c).

\subsubsection{A Wider Framework}

Moving beyond the quantitative assessment of the impacts on economic growth of various 'inputs' is the question of what makes some countries accumulate more human capital than others or what makes them more efficient than others in the use of such inputs. The work by Hall and Jones (1999) is a first investigation of the role of wider influences on growth - the 'fundamental' causes of economic performance - which may work through the proximate sources of input (physical and human capital) accumulation, or may also have a direct impact through total factor productivity. The wide-ranging notion they use, 'social infrastructure', relates to those institutions and government policies that shape the economic environment in which private agents - individuals and firms - make their investment decisions. A good social infrastructure gets the prices right, so that agents 
capture the social returns of their activities, be it productive activities, capital accumulation, skill acquisition, invention or technological transfer and adoption.

Economic performance, as represented by output per worker, appears to be strongly associated with measures of this fundamental cause of growth, social infrastructure, as proxied by combining an index of government anti-diversion policies ${ }^{12}$ and an index of openness to international trade. ${ }^{13}$ Similarly, a good social infrastructure appears to be positively correlated to the proximate sources of economic performance, by stimulating both physical and human capital accumulation, as well as by positively affecting residual productivity.

Temple (2001) provides a survey and a tentative summary of the growth impact of a related concept, that of 'social capital'. Empirically measured in recent work by the extent of trust in a society (as collected by the World Values Survey), social capital appears to be positively correlated with a country's economic success, although the results are not very robust and are much weaker when confined to the OECD alone. There is also some evidence that like Hall and Jones' social infrastructure, trust is positively correlated with investment and educational attainment, though especially for the latter a reverse causality problem may exist.

\subsubsection{Delivery of Education and Schooling Inputs}

As with the micro literature trying to assess the wage return to measured schooling quality, the few macro studies aiming at identifying a potential role for educational inputs in economic performance fail to find any significant effect.

As to per capita GDP growth, the student-teacher ratio at neither the primary nor secondary level is significant, with only the one for primary schools showing the expected negative sign (Barro, 1991).

As to the measure of quality (student cognitive achievement as captured by test scores), inputs into education (such as the pupil-teacher ratio and a long list of schooling expenditure variables) do not display any systematic significant effect, their estimated impact being either statistically insignificant, or significant but with the wrong sign (Hanushek and Kim, 1995).

Thus the important result that labour force quality offers a very important contribution to growth (cf. 4.3.3) lacks specific policy prescriptions, since no relationship has apparently been found between that measure of quality and measured inputs into schooling.

\section{Future Research Options}

Despite the numerous interesting insights offered by this literature, the empirical evidence is still weak at various crucial points. Currently some progress is being made on the following issues, but much more needs to be done.

Does education affect the growth or the level of productivity?

This has been a major area of work, but there is still no consensus. Part of a serious examination of this issue needs to pay much more attention to the measurement of human capital. As Krueger and Lindahl (1998) stress, there is 
considerable measurement error, especially in the LDCs and more attention needs to be given to the stock versus flow of human capital distinction. The failure to find any effect of the growth of human capital on the growth of productivity (e.g. Benhabib and Spiegel, 1994) is suggestive of problems of measurement.

\section{Reconciling micro with macro}

There is an urgent need to push further in estimating at different levels of aggregation (as has occurred in the R\&D and productivity literature). There are now large datasets available with education, wage and productivity data at individual, enterprise, industry and economy-wide levels. More attention should be paid to matching enterprise data with human capital to estimate the effect of schooling on productivity within and between firms. The work of Moretti (1999) and Angrist and Acemoglu (1999) on US wages are examples of alternative approaches to macro-style equations.

\section{Reverse Causality}

Endogeneity has been a major pre-occupation of the micro literature (e.g. Card, 1999) but hardly features at all in the macro literature. Yet growth may clearly be the cause rather than the consequence of education. More careful attention needs to be paid to this issue, and the sources of identifying information which exogeneously change education need to be examined.

\section{Mechanisms between education and growth}

An overarching issue is that although we now have more knowledge of which factors affect growth, our understanding of both the mechanisms that create this impact and of the determinants of international variation in the accumulation or use of these factors is still poor. Thus although the available evidence does point out that human capital has a positive impact on growth, further research is still needed to investigate precisely how a higher level or a faster accumulation of human capital translates into faster growth or higher productivity. Similarly, the question of why some countries accumulate more human capital than others or are more efficient at using this as well as other inputs still needs to be thoroughly addressed. (An initial step in this direction is offered by the work of Hall and Jones, 1999).

\section{Quality}

It might be dubious to compare the quantity of schooling across countries which have very diverse educational systems. In addition, it would be very interesting to know how differences in schooling systems impact on productivity in the labour market and economic performance. A related interesting but unanswered question in the presence of a government education budget constraint concerns the possibility of a trade-off between quality and quantity of education. Leaving equity issues aside, what matters most for growth: breadth of access or school quality? Should governments concentrate resources in expanding education aiming at increasing the percentage of the population covered by basic education in less developed countries and encouraging more individuals to go on to further education in industrialised countries - or rather in improving the quality of educational structures for existing students? 
It has to be stressed, though, that such considerations apply to a context where the education system is in fact operating efficiently. By contrast, where the system is inefficient, it is possible to both widen the access of students to education and improve the quality of education without any increased spending. By adopting efficient modes of educational delivery ${ }^{14}$, both better coverage and better quality may be achievable.

\section{Stages and types of education}

As discussed in 4.1.3, there is still no reliable information regarding the relative growth returns of pre-school, primary, secondary and higher education, as well as of different types of education (e.g. vocational versus academic).

\section{Training}

As mentioned in 3.1 and 4.3.2, the macro literature focuses on measures of human capital which ignore formal (and informal) on-the job training, nor has it explored to date the possibility for education to have an indirect positive effect on economic growth by fostering training.

\section{Are sustained improvements in educational attainment bound to lead to increased growth?}

It would prove extremely fruitful to identify the conditions under which expanding education is most beneficial. Issues which would deserve empirical investigation in this context include the question of whether there are decreasing returns to the expansion of education (possibly via declining average ability due to the expansion of schooling; cf. 4.1.3). In particular, the incremental value of additional education in countries where average length of schooling is already high is less obvious, and probably largely depends on the type and quality of education. Connected to this is the question of whether there is a limit to the contribution of education to growth. Industrialised countries have reached the upper bound for measures such as literacy rates and primary school enrolment rates, and in principle the upper bound for secondary and then tertiary schooling rates could also be attained. ${ }^{15}$ Finally, research should investigate the possible presence of general equilibrium effects of national policies designed to promote the acquisition of skills. Under normal conditions, an increased supply of educated workers would depress its relative return. In the context of the new growth theories, however, the expansion in the supply of educated labour is seen as being itself a cause of (possibly skill-biased) technological change so that it would raise the economy's growth rate and thus maintain or increase the educational wage premium. The rising relative wage of skilled workers observed in some countries in the presence of an increasing supply of educated labour does in fact suggest the presence of a rapidly expanding demand for skills. Perraton (1998) rightly emphasises that although in principle an increased supply of educated labour can lead to transformations in the economy that will ensure the demand for it, in practice, a number of conditions in the national political economy - not yet fully understood - appear also to be needed. 
Although all these problems and needs may seem rather discomforting, it is worth re-iterating the words from the author of a recent overview of the growth literature, Temple (1999, p. 151, 152):

'it is certainly true that, taken as a whole, the growth literature can seem something of a disappointment, [...] it is always worth remembering how little we knew when we started'.

\section{Conclusions}

In summary we will reiterate our main conclusions from the literature.

From the theoretical point of view, there is an important distinction between studies in the neo-classical tradition and the new growth theories. The former argue that a one-off permanent increase in the human capital stock will be associated with a one-off increase in the economy's growth rate, until productivity per worker hour has reached its new (and permanently higher) steady-state level. New growth theories by contrast argue that the same one-off increase in human capital will be associated with a permanent increase in the growth rate. The social benefits of education will clearly tend to be much greater in this case.

From the methodological point of view, the estimation of macro economic production functions including education as a regressor presents a host of still unresolved issues. The most important of these are the measurement of human capital (poor proxies of the theoretical concepts; affected by measurement error), systematic differences in parameters across countries (e.g. developing vs. developed countries) and reverse causality (faster growing countries invest more in education).

The estimates of the impact of human capital on economic performance which have been produced by the various studies reviewed are not directly comparable, due to different dependent variables, proxies for human capital (flows or stocks; primary, secondary or tertiary) and samples (in particular, including or excluding less developed countries). Nonetheless, taking the studies as a whole, there is compelling evidence that human capital increases productivity, suggesting that education really is productivity-enhancing rather than just a device that individuals use to signal their level of ability to the employer.

Most evidence is from 'Barro' style growth regressions which suggest that increasing school enrolment rates by one percentage points leads to an increase in per capita GDP growth of between 1 and 3 percentage points. The empirical literature is however still largely divided on whether the stock of education affects the long-run level or growth rate of the economy. Increasing average education in the population by one year would raise the level of output per capita by between 3 and 6 percent according to augmented neo-classical specifications, while it would lead to an over 1 percentage point faster growth according to new-growth theories estimates.

The implied effects of the stock of human capital on growth appear implausibly large in the 'new growth' approach. We think the effect is overstated due to methodological problems such as correlation with omitted variables, (datarejected) restrictions of homogeneity and linearity of impact, all of which cast 
serious doubts on the interpretation of such 'new growth' evidence as educational economy-wide spill-overs. A study exploring the issue of linearity of educational impacts does in fact find this commonly imposed restriction to be rejected by the data, which instead reveal an inverted-U shaped relationship between initial stock of human capital and economic growth, peaking below the average OECD education. The finding that the average OECD country is found to be on the downward-sloping portion of the education-growth profile further weakens the evidence in favour of the new growth theories (especially for OECD countries).

The neo-classical approach by contrast generates effects that are both more reasonable on a priori grounds and more consistent with the micro-economic evidence. Our baseline estimates follow Mankiw, Romer and Weil (1992) and similar, more recent work by de la Fuente and Doménech (2000) and Bassanini and Scarpetta (2001) which focuses on OECD, and look for effects of human capital on the level of output, although we compare this carefully with estimates from the alternative approach. Interestingly, it turns out that over the short-run planning horizon (4 years ahead) the empirical estimates of the change in GDP for a given increase in the human capital stock are of similar orders of magnitude in the two approaches.

The most robust qualitative results include:

- The factors that appear to have an important impact on growth in samples including both OECD and developing countries have traditionally been found to be considerably less precise and have much less explanatory power when estimated for the OECD sub-sample alone. Some promising very recent contributions based on a new harmonised dataset for the OECD, as well as on more sophisticated techniques exploiting the time-series dimension of the data have however obtained significant and robust estimates in models with high explanatory power.

- The impact of increases in various levels of education appears to vary greatly according to the level of a country's development. In particular, while primary and secondary skills appear to be related to growth in the poorest and in intermediate developing countries respectively, it is tertiary skills that are important for growth in OECD countries.

- In addition to its direct contribution to growth, human capital has indirect effects as well, by stimulating the accumulation of other productive inputs (e.g. physical capital, technology or health) which in turn foster growth, while discouraging factors (like population growth or infant mortality) which hamper growth.

More preliminary evidence seems to indicate that type, quality and efficiency of education all matter for growth:

- the measured growth returns to engineers appear to be higher than those to lawyers;

- labour force quality has a significant and positive impact on growth; such a result however lacks policy implications, since measured educational inputs 
fail to affect labour force quality, nor do they seem to directly affect economic growth;

- the contribution of human capital to growth has been found to depend on the efficiency with which resources are allocated to the various levels of education.

There are many methodological and conceptual problems in this literature, but it does give some guidance for policy. Taken as a whole we feel confident that there are important effects of education on growth. We are less confident that the effects of education on growth are as large as it is claimed by the new growth literature. There needs to be a much more concerted attempt to combine the new growth theory with rigorous micro-studies to demonstrate the link between innovation and human capital, in particular work reconciling micro and macro evidence by combining data at different levels of aggregation (individual, firm, industry and economy-wide). Other main research areas that need supporting include better attempts to control for reverse causality by using more exogenous changes affecting education, in parallel to the quasi-experimental approach adopted in the estimation of private returns by labour economists. Improving the (timevarying) measurement of the stock of human capital, taking account of quality issues as well as of further investments in the form of training, should also be high on the agenda. Finally, a more policy-oriented approach would attempt to open up the 'black box' of education by trying to explore the mechanisms through which human capital affects growth, for instance by looking at more disaggregated issues in more detail and in a more satisfactory way than done to date.

\section{Acknowledgements}

This research has been funded by the Department for Education and Employment. We would like to thank Stephen Redding, members of the DfEE, Ian Walker and other colleagues at IFS for many helpful comments.

\section{Appendix}

An appendix with a one page summary of each paper including abstract, data, method, results and critique is available in the working paper version 'The returns to education: A review of the empirical macro-economic literature' on www.ifs.org.uk/workingpapers/ wp0205.pdf.

\section{Notes}

1. An economically efficient decision as to public spending on education would need to consider how much larger the social returns are compared to the private ones.

2. These assumptions imply that the price of factor $n$ is equal to its marginal product $\left(p_{n}=M P_{n}\right)$ and that factor shares exhaust output $\left(p_{k} K+p_{l} L=Y\right)$.

3. Gemmel (1996) in particular attempts to bring some order in the confusing use in empirical studies of human capital variables supposedly proxying human capital levels 
or flows. The author shows that school enrolment rates - commonly (and wrongly) used to proxy both stocks of and investments in human capital - confound the effects of human capital stock and accumulation and cause coefficients on labour growth variables to partly include the effects of human capital.

4. Most OECD countries have passed this peak (average is 8.4 years for OECD in BarroLee) implying that, at the margin, additional years of schooling have a negative effect on productivity.

5. Note that the coefficient on the growth of human capital combines both an endogenous growth effect and a neo-classical effect. This is why the coefficient is larger than on the stock.

6. No authors comment on the relative size of increases in flows and stocks of human capital. In fact, one should not try to compare them, since stock and flows - even when (though rarely) both considered in the same study - are measured in different units, so that 'a 1 percentage point increase' does not mean the same increment when related to flows (like school enrolment rates) or stocks (like the constructed measure of Gemmel, 1996). In addition, the increase in the stock is often in terms of average numbers of years.

7. Nonneman and Vanhoudt (1996) explore the alternative explanation that not all relevant factors of production have been included. They further extend the augmented Solow model used by Mankiw, Romer and Weil (1992) by including technological know-how. For the same OECD sub-sample used by the latter authors, their model has a considerably higher explanatory power, although the influence of human capital becomes insignificant.

8. This might seem like a small number, but we are considering plausible policy reforms. Where secondary schooling is compulsory the main margin would be increased participation of $16-18$ year olds.

9. These recent contributions focused on the OECD have not yet experimented with the simultaneous inclusion of human capital growth and initial level.

10. Using a calibrated model, Bils and Klenow (2000) for instance find that the impact of schooling on growth can explain at most one third of the observed Barro-style positive relation between initial schooling and subsequent per capita growth rates.

11. Examples: an exogenous change (in particular, a rise) in the returns to education has taken place; the stock of education may be picking up the effect of the omitted change in education; or education may be a proxy for steady-state income. For more details, see Topel (1999) and Krueger and Lindahl (1998).

12. These policies are summarised in the ratings given to the country in terms of: law and order, bureaucratic quality, corruption, risk of expropriation and government repudiation of contracts.

13. Recognising that social infrastructure may be endogenous (i.e. may itself depend on the economy's level of output per worker) and that the proxy used may recover it with measurement error, the authors instrument their social infrastructure indicator with various geographical and linguistic correlates to the extent of Western European influence. The idea is that Western Europe has discovered the key tenets of a favourable social infrastructure (e.g. property rights, the ideas of Adam Smith, the system of checks and balances), while European influence was not likely to be targeted towards regions nowadays more likely to have high output per worker.

14. For example the adoption and effective use of information technology (particularly the internet) may allow a large number of students to be reached at relatively low cost and in ways which are at least as effective in terms of educational outcomes as traditional teaching methods. 
15. As Hanushek and Kimko (2000) point out, in many theoretical models continued growth arising from human capital would require continued growth in human capital. In such a framework it is more natural to conceive unbounded growth of human capital in quality (e.g. cognitive skills) terms, rather than in terms of years of education.

\section{References}

Acemoglu, D. and Angrist, J. (1999) How large are the social returns to education? Evidence from compulsory schooling laws. mimeo, MIT.

Aghion, P. and Howitt, P. (1998) Endogenous Growth Theory. Cambridge, MA: MIT Press.

Angrist, J. and Krueger, A. (1991) Does compulsory school attendance affect schooling and earnings? Quarterly Journal of Economics, 106, 979-1014.

Barro, R. (1991) Economic growth in a cross section of countries. Quarterly Journal of Economics, 106, 407-443.

Barro, R. (1997) Determinants of economic growth: A cross-country empirical study. Cambridge, MA: MIT Press.

Barro, R. and Lee, J.-W. (1994) Sources of economic growth. Carnegie-Rochester Conference Series on Public Policy, 40, 1-46.

Bassanini, A. and Scarpetta, S. (2001) The driving forces of economic growth: Panel data evidence for the OECD countries. OECD Economic Studies, 33, 9-56.

Benhabib, J. and Spiegel, M. (1994) The role of human capital in economic development: Evidence from aggregate cross-country data. Journal of Monetary Economics, 34, 143-173.

Bils, M. and Klenow, P. (2000) Does schooling cause growth? American Economic Review, $90,1160-1183$.

Blundell, R., Dearden, L., Meghir, C. and Sianesi, B. (1999) The returns from education and training to the individual, the firm and the economy: A review of the theoretical and empirical literature. Technical Report to the DfEE Skills Task Force, London: Institute for Fiscal Studies.

Blundell, R., Dearden, L. and Sianesi, B. (2002) Estimating the returns to education: Models, methods and results. Journal of the Royal Statistical Society Series A, forthcoming.

Cameron, G., Proudman, J. and Redding, S. (1998) Productivity convergence and international openness. In J. Proudman and S. Redding (eds), Openness and Growth (Chapter 6). Bank of England, London.

Card, D. (1999) The causal effect of education on earnings. In O. Ashenfelter and D. Card (eds), The Handbook of Labour Economics (Chapter 30). Amsterdam: North Holland.

Currie, J. (2001) Early Childhood Education Programs. Journal of Economic Perspectives, $15,213-238$.

Dearden, L., Reed, H. and van R. J. (2000) Who gains when workers train? Training and corporate productivity in a panel of British industries, IFS working paper 00/04.

de la Fuente, A. and Doménech, R. (2000) Human capital in growth regressions: How much difference does data quality make? mimeo, Universidad Autónoma de Barcélona, January.

Englander, S. and Gurney, A. (1994) Medium-term determinants of OECD productivity. OECD Economic Studies, 22, 49-109.

Gemmell, N. (1996) Evaluating the impacts of human capital stocks and accumulation on economic growth: some new evidence. Oxford Bulletin of Economics and Statistics, 58, 9-28.

Griffith, R., Redding, S. and van R. J. (2000) Mapping the two faces of R\&D: Productivity, R\&D, skills and trade in an OECD panel of industries, mimeo, Institute for Fiscal Studies. 
Griliches, Z. (1996) The discovery of the residual: A historical note. Journal of Economic Literature, 34, 1324-1330.

Griliches, Z. (1997) The Simon Kuznets Memorial Lectures, draft, October.

Hall, R. and Jones, C. (1999) Why do some countries produce so much more output per worker than others? Quarterly Journal of Economics, 114, 83-116.

Hanushek, E. and Kim, D. (1995) Schooling, labor force quality, and economic growth. NBER Working Paper: 5399.

Hanushek, E. and Kimko, D. (2000) Schooling, labor force quality, and the growth of nations. American Economic Review, 90, 1184-1208.

Harmon, C., Oosterbeek, H. and Walker, I. (2002) The returns to education: microeconomics. Journal of Economic Surveys, 17, 115-155.

Jenkins, H. (1995) Education and production in the United Kingdom. Nuffield College, Oxford, Economics Discussion Paper No. 101

Jorgenson, D. and Fraumeni, B. (1992) Investment in education and U.S. economic growth. Scandinavian Journal of Economics, 94, S51-70.

Judson, R. (1998) Economic growth and investment in education: How allocation matters. Journal of Economic Growth, 3, 337-370.

Klenow, P. and Rodriquez-Clare, A. (1997) The neoclassical revival in growth economics: Has it gone too far? NBER Macroeconomics Annual, 73-103.

Krueger, A. and Lindahl, M. (1998) Education for growth: Why and for whom? mimeo, Princeton University.

Lee, K., Pesaran, H. and Smith, R. (1997) Growth and convergence in a multi-country empirical stochastic Solow model. Journal of Applied Econometrics, 12, 357-392.

Levine, R. and Renelt, D. (1992) A sensitivity analysis of cross-country growth regressions. American Economic Review, 82, 942-963.

Mankiw, N. G., Romer, D. and Weil, D. (1992) A contribution to the empirics of economic growth. Quarterly Journal of Economics, 107, 407-437.

Moretti, E. (1999) Estimating the external return to education: evidence from repeated cross-sectional and longitudinal data, mimeo, Berkeley, University of California.

Murphy, K., Shleifer, A. and Vishny, R. (1991) The allocation of talent: Implications for growth. Quarterly Journal of Economics, 106, 503-30.

Nonneman, W. and Vanhoudt, P. (1996) A further augmentation of the Solow model and the empirics of economic growth for OECD countries. Quarterly Journal of Economics, 111, 943-953.

OECD (1998) Returns to investment in human capital. Ch. 4 in Human capital investment An international comparison, Paris: OECD, Centre for Educational Research and Innovation.

Perraton, J. (1998) Debate: education and growth, Introduction. New Political Economy, 3, $121-123$.

Solow, R. (1957) Technical change and the aggregate production function. Review of Economics and Statistics, 39, 312-320.

Temple, J. (1998) Robustness tests of the augmented Solow model. Journal of Applied Econometrics, 13, 361-375.

Temple, J. (1999) The new growth evidence. Journal of Economic Literature, 37, 112-156.

Temple, J. (2001) Growth effects of education and social capital in OECD countries. OECD Economic Studies, 33, 57-101.

Topel, R. (1999) Labour market and economic growth. In O. Ashenfelter and D. Card (eds.), The Handbook of Labour Economics (Chapter 44). Amsterdam: North Holland. 